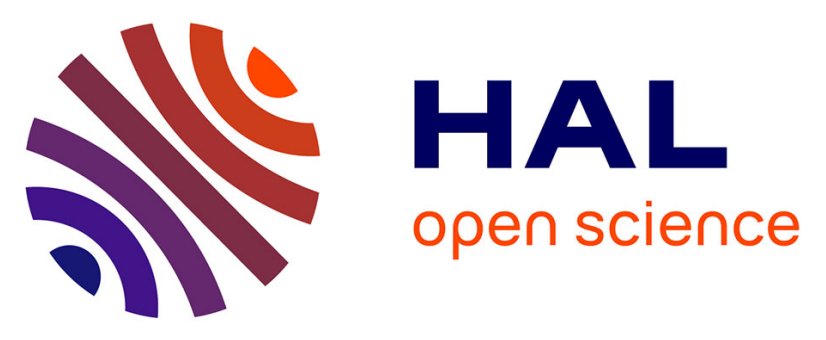

\title{
Basin scale distribution of organic matter in marine fine-grained sedimentary rocks: Insight from sequence stratigraphy and multi-proxies analysis in the Montney and Doig formations
}

\author{
Vincent Crombez, François Baudin, Sébastien Rohais, Laurent Riquier, \\ Tristan Euzen, Stanislas Pauthier, Mathieu Ducros, Benoît Caron, Noga \\ Vaisblat
}

\section{- To cite this version:}

Vincent Crombez, François Baudin, Sébastien Rohais, Laurent Riquier, Tristan Euzen, et al.. Basin scale distribution of organic matter in marine fine-grained sedimentary rocks: Insight from sequence stratigraphy and multi-proxies analysis in the Montney and Doig formations. Marine and Petroleum Geology, 2017, 83, pp.382-401. 10.1016/j.marpetgeo.2016.10.013 . hal-01386739

\section{HAL Id: hal-01386739 \\ https://hal.sorbonne-universite.fr/hal-01386739}

Submitted on 24 Oct 2016

HAL is a multi-disciplinary open access archive for the deposit and dissemination of scientific research documents, whether they are published or not. The documents may come from teaching and research institutions in France or abroad, or from public or private research centers.
L'archive ouverte pluridisciplinaire HAL, est destinée au dépôt et à la diffusion de documents scientifiques de niveau recherche, publiés ou non, émanant des établissements d'enseignement et de recherche français ou étrangers, des laboratoires publics ou privés. 


\section{sedimentary rocks: insight from sequence stratigraphy and multi-}

1 - IFP Energies nouvelles, 1 et 4 Avenue de Bois-Préau, 92500, Rueil-Malmaison, France.

2 - Sorbonne Universités, UPMC Univ. Paris 06, CNRS, ISTeP, 75005, Paris, France.

3 - IFP Technologies (Canada) Inc., Suite 810, 744 - 4th Avenue S.W., Calgary, Alberta, Canada.

4 - Department of Earth and Atmospheric Sciences, University of Alberta, 1-26 ESB, Edmonton, Alberta, Canada.

* Corresponding author e-mail: crombez.v@gmail.com Revised manuscript submited to: Marine and Petroleum Geology

The $15 / 09 / 2015$

ABSTRACT ....... 
5.2. Spatial variations and temporal evolution of primary productivity, anoxia and dilution and 
41

42

43

44

45

46

47

\section{ABSTRACT}

The occurrence of hydrocarbons in self-sourced reservoirs strongly depends on the concentration and maturity of organic matter in sediments. Therefore, understanding the distribution of organic heterogeneity at the time of deposition is key to reduce the risk in exploration and development of unconventional resources. This study focuses on the Lower and Middle Triassic Montney and Doig Formations (Alberta and British Columbia). Samples from outcrops, cores and cuttings were analyzed for organic content with a Rock-Eval VI and for major and trace element concentration using ICP-MS and ICP-AES techniques. The interpretation of the analysis results in relation with the stratigraphic architecture provides a mean to better understand the distribution of the organic heterogeneities and the variations of primary productivity, sedimentation rates and anoxia that control the development of source rocks.

The key findings of this analysis are:

- The basin-scale distribution of the organic matter suggests that the two major source-rock intervals of the Lower and Middle Triassic correspond to the sequence 3 (Spathian Montney unit) and to the transgressive systems tract of sequence 4 (Doig phosphate zone).

- The dominant controls on organic matter accumulations vary through time. The Montney source-rock interval is interpreted to be associated with a major basin restriction triggering anoxia during a second-order falling stage of relative sea level. The organic accumulation of the Doig phosphate zone is interpreted as being controlled by a sharp decrease of the sedimentation rate, combined with an increase of the primary productivity.

- The spatial and temporal variations of anoxia, primary productivity and dilution reflect the geodynamic evolution of the basin that ultimately controls the basin physiography as well as the sources of nutrient and sediments.

\section{HIGHLIGHTS}

The Montney and Doig Formations mainly present amorphous organic matter. 
Rock-Eval data integration in stratigraphic framework shows two organic rich layers.

$\mathrm{Ni}$ and $\mathrm{Cu}$ variations suggest an increased primary productivity in the Doig Phosphate.

Redox proxies suggest anoxic intervals in the Upper Montney and the Doig Phosphate.

\section{KEYWORDS}

Petroleum source rocks; Triassic; Montney and Doig Formations; Organic matter; Primary productivity; Redox conditions; Sedimentation rates; Canada.

\section{INTRODUCTION}

With the development of self-sourced and closely associated tight reservoirs, there is a need for a better understanding of the origin and distribution of primary organic matter (OM) in source rocks (Schwarzkopf, 1993; Tommeras and Mann, 2008; Ducros et al., in press). Stratigraphic framework characterization is the first and main step needed to quantify and discuss the processes controlling the distribution of OM (Creaney and Passey, 1993; Myers, 1996; Huc et al., 2005; Van Buchem et al., 2005; Slatt and Rodriguez, 2012). Such integrated workflow gathering information on organic productivity, preservation and dilution at basin scale remains a challenge especially as geodynamic and climatic setting induce a large diversity of organic-rich deposits (Huc et al., 2005).

Our work focuses on one of the largest unconventional play of Canada: the Montney and Doig Formations of the Lower and Middle Triassic interval ( $252-235 \mathrm{Ma})$ of Western Canada. The amount of data available due to an extensive oil and gas exploration in the area and the presence of time equivalent outcrops in the fold and thrust belt of the Canadian Cordillera, makes this interval an attractive case study to analyze OM distribution in sedimentary basins. This study is built on a database including core, cutting and outcrop descriptions and samples as well as wireline logs. Geochemical and organic petrographical analyses (palynofacies, Rock-Eval, Major and Trace Metal Elements) were then performed on selected samples. Finally, the results were integrated in a 
sequence stratigraphic framework in order to discuss the main factors controlling the distribution of OM in the studied interval.

\section{THE MONTNEY AND DOIG FORMATIONS}

\subsection{Generalities}

The Montney, Doig and Halfway Formations are preserved in the foreland basin of the Canadian Cordillera and in time equivalent outcrops in its fold and thrust belt (figure 1). These Lower and Middle Triassic Formations have been studied since the 60's (Armitage 1962). The Montney and Doig Formations are mostly composed of fine-grained dolomitic sandstone and siltstone with subordinate amount of shale and moderate clay content (Davies, 1997a; Zonneveld et al., 2010; Chalmers and Bustin, 2012; Euzen et al., 2015). They were deposited on the western margin of Pangea (Davies et al., 1997). This location is considered as a passive margin during the Devonian and a foreland basin during the Jurassic. Doubts remain on the precise paleogeographic settings: foreland basin (Golding et al., 2015a) versus passive margin during the time of the deposition of the studied interval (Monger and Price, 2002).

\subsection{Stratigraphic settings and chronostratigraphy}

The stratigraphic framework used in this paper is based on a recent regional sequence stratigraphic interpretation of the Lower and the Middle Triassic in the Western Canada Sedimentary Basin (e.g. Crombez, 2016). Based on more than 400 wells, it shows that the studied interval can be subdivided into two second-order sequences $A$ and $B$ and that sequence $A$ can be further subdivided into three third order sequences 1,2 and 3 . Within sequence $A$, the maximum backstepping of the sedimentary system occurs during the second sequence (figure 2). Based on the biostratigraphic works of Orchard and Zonneveld (2009) and Golding et al. (2015b), sequence A and B are respectively Lower Triassic and Middle Triassic in age. Within sequence $A$, sequence 2 was deposited above the InduanOlenekian boundary and sequence 3 lays on top of the Smithian-Spatian boundary. According to biostratigraphic data, the top of sequence B is older than the Ladinian-Carnian boundary (Orchard 
and Zonneveld, 2009). Integrating these recent developments (Crombez, 2016) in Davies et al., 1997 stratigraphic framework, the Montney Formation corresponds to sequence A. In this first second order sequence, sequence 1 can be considered as the Lower Montney, the sequence 2 as the Middle Montney and sequence 3 as the upper Montney whereas the Doig and Halfway Formations are part of sequence B. As the Montney Formation is interpreted as a second order cycle, the sequence 1 and the transgressive system tract (TST) 2 therefore represents a second order TST, the sequence 2 a second order HST and the sequence 3 a second order FSST (Crombez, 2016). From this work, as sequence B records the expression of a second order cycle, TST4 and HST4 can be considered as second order system tracts or third order sequences.

The figure 2 illustrates the position of the studied well and outcrop (restored location) sections within the stratigraphic framework of the basin. A recent study suggests that the Montney and Doig Formations were deposited in a fore-arc basin connected with the open marine setting to the Northwest (Rohais et al., 2016). The stratigraphic architecture of sequence A suggests a basin with a WNW-ESE axis and sedimentary inputs coming from East and Southeast. The distribution of thickness and facies in sequence B suggests a NW-SE basin axis with an additional sedimentary source to the West (Error! Reference source not found.). This change in sediment source areas and the clockwise rotation of the basin axis are interpreted to be linked to the evolution of the proto-Canadian Cordillera (Crombez, 2016; Rohais et al., 2016).

\section{DATA AND METHODS}

\subsection{Data}

For this study, data were collected from both outcrop in the Canadian Cordillera and subsurface in the foreland basin (figure 1). In Alberta, the cuttings from the Montney-Doig-Halfway intervals were sampled in 7 wells and in addition, 14 cores were also sampled. In British Columbia, the cuttings of the studied interval were sampled in 3 wells. Moreover, 4 cores including a $300 \mathrm{~m}$ long core and one outcrop (Brown Hill, BH on figure 1) were sampled. In total, 365 samples collected from cores, 498 
from cuttings and 176 from outcrops were available for this work. The results of the present study is illustrated along a SE-NW section composed of 7 wells with cuttings sampled each $5-10 \mathrm{~m}$ and a $300 \mathrm{~m}$ long core, sampled each 5-10m, with additional constraints from both outcrops and subsurface (figure 1).

\subsection{Methods}

The workflow developed for this study unfolds as follow: (1) The characterization of the organic content in the studied interval, using Rock-Eval analyses (Espitalie et al., 1986; Behar et al., 2001) and palynofacies study (Tyson, 1995). (2) The study of the distribution of the organic rich layers in the stratigraphic framework. (3) The study of paleoenvironmental conditions through variations of major and trace element concentrations and mineralogy in order to highlight the dynamic of the primary productivity, the dilution by non-organic element and the $\mathrm{O}_{2}$ levels along four sections (Brumsack, 2006; Tribovillard et al., 2006; Algeo and Tribovillard, 2009 and references herein).

\subsubsection{Rock-Eval pyrolysis and hydrocarbons extraction}

Routine source rock analyses were carried out on 900 samples with a Rock-Eval VI. The bulk-rock basic cycle, used for these routine analyses, is described by Behar et al. (2001). 50 to $70 \mathrm{mg}$ of powdered sample is heated in an open pyrolysis system under non-isothermal condition (from $300^{\circ} \mathrm{C}$ to $650{ }^{\circ} \mathrm{C}$ ). During this pyrolysis, the amount of hydrocarbons released is measured by a flame ionization detector (FID) and $\mathrm{CO}$ and $\mathrm{CO}_{2}$ release are monitored with an infrared (IR) detector. The residual sample is then put in an oxidation oven where it is heated (from $300{ }^{\circ} \mathrm{C}$ to $800{ }^{\circ} \mathrm{C}$ ) under artificial air $\left(\mathrm{N}_{2} / \mathrm{O}_{2}: 80 / 20\right)$. During this combustion, the amount of $\mathrm{CO}$ and $\mathrm{CO}_{2}$ released are monitored with an IR detector.

In addition to the bulk-rock samples, organic solvent extraction was performed on selected samples. The powdered sample was placed in a solution of dichloromethane and methanol $(1 / 1)$ in an ultrasonic bath for $30 \mathrm{~min}$. The sample was then filtered and placed in a drying oven for $30 \mathrm{~min}$. Finally the sample was analyzed with the basic Rock-Eval method described above. 


\subsubsection{Palynofacies}

In addition to the source rock evaluation, palynofacies analyses were carried out on 26 selected samples. The preparation of the samples consists in the dissolution of $2 \mathrm{~g}$ of crushed rock in successive acid bath. The sample was placed in a cold solution of hydrochloric acid (70 \%) for 180 min. After multiple rinsing, the residual sample was placed in a cold solution of hydrofluoric acid (70 \%) for $180 \mathrm{~min}$. Again, after multiple rinsing, the residual sample is place in a hot $\left(40{ }^{\circ} \mathrm{C}\right)$ solution of hydrochloric acid (70 \%) for 180 min. Finally, after multiple rinsing, the residual sample was sieved with a $15 \mu \mathrm{m}$ filter and the filtrate was mounted between two glass slides.

The slides were then observed with an optical microscope under different magnifications in order to classify the organic particles in three categories following the classification of Tyson (1995): the amorphous organic matter (AOM), the phytoclasts and the palynomorphs.

\subsubsection{Initial TOC computation}

In order to better understand the distribution of organic matter at the time of deposition (before thermal maturation), Rock-Eval analysis and palynofacies were used to estimate the initial total organic carbon ( $\mathrm{TOC}_{\text {ini) }}$ ). The equation (Equation Error! Reference source not found.1) used for the computation of the $\mathrm{TOC}_{\mathrm{ini}}$ is based on carbon mass balance and is similar to the formula proposed by Jarvie (2012).

$$
T O C_{\text {ini }}=\frac{T O C-(S 1+S 2) \times 0.083}{1-\left(H I_{\text {ini }} / 1200\right)}
$$

(Equation 1)

This equation uses the total organic carbon (TOC), the free hydrocarbons (S1) and the oil potential (S2) from Rock-Eval analysis, and requires an estimation of the initial hydrogen index $\left(\mathrm{HI}_{\text {ini }}\right)$. The $\mathrm{HI}_{\text {ini }}$ was estimated using the palynofacies analyses that provide insight into the nature and quality of the OM. The values of $\mathrm{HI}_{\text {ini }}$ used in this study are $700 \mathrm{mgHC} / \mathrm{gTOC}$ for type I organic matter, 450 mgHC/gTOC for type II and 125 mgHC/gTOC for type III (Espitalié et al., 1986; Jarvie et al., 2007). 
Elementary analyses of samples from wells 0/14-14-76-12W6 and 0/06-33-72-25W5 and from Brown

Hill outcrop were performed with an ICP-MS for trace elements and an ICP-AES for major elements.

Samples were powdered with an agate mortar beforehand. Then, $50 \mathrm{mg}$ of sample was solubilized

using a solution of hydrochloric acid (70 \%) and a solution of boric acid (45\%). In order to dissolve

entirely the OM, $2 \mathrm{ml}$ of a hydrogen peroxide solution were added to the samples with a high TOC.

The residual samples were then diluted 10,000 times for the ICP-MS analyses and 1,000 for the ICP-

AES analyses. International (ATHO-G from Borisova et al., 2010; AGV-1, BCR-2, BH-VO2 and BIR-1

In order to investigate the vertical and the lateral variations of metal trace elements (MTE), the concentration of MTE was divided by the Aluminum content of the sample and normalized to the upper continental crusts (UCC) by computing an enrichment factors (EF) (Taylor and McLennan, 1985; McLennan, 2001):

$$
E F_{E}=\frac{[E]}{[A l]} \text { sample } / \frac{[E]}{[A l]} U C C \quad \text { (Equation 2) }
$$
concentration of aluminum (ppm). 
In addition to core and outcrop descriptions, cuttings from one well were sampled in order to quantify the mineralogy of the Triassic strata. QEMSCAN analyses (Gottlieb et al., 2000) were performed by SGS Canada Inc. on 72 samples. QEMSCAN automated mineralogical analysis is based on backscattered-electron imaging and energy dispersive X-ray spectroscopy techniques.

\subsubsection{Weathering index of Parker (WIP) and chemical index of alteration (CIA)}

214

Based on elemental major element concentrations, the weathering index of parker (WIP, Parker, 1970) and the chemical index of alteration (CIA, Nesbitt and Young, 1982) provide information on the maturity of siliciclastic sediments:

$$
\begin{gathered}
W I P=\left(\frac{[\mathrm{Na}]^{*}}{0.35}+\frac{[\mathrm{Mg}]^{*}}{0.9}+\frac{[\mathrm{K}]^{*}}{0.25}+\frac{[\mathrm{Ca}]^{*}}{0.7}\right) \times 100 \quad \text { (Equation 3) } \\
C I A=\left(\frac{\left[\mathrm{Al}_{2} \mathrm{O}_{3}\right]}{\left[\mathrm{Al}_{2} \mathrm{O}_{3}\right]+\left[\mathrm{Na}_{2} \mathrm{O}\right]+\left[\mathrm{K}_{2} \mathrm{O}\right]+[\mathrm{CaO}]}\right) \quad(\text { Equation 4) }
\end{gathered}
$$

Where $[E]$ is the atomic concentration of $E(p p m)$ and $[E]^{*}$ represent the atomic concentration of an element divided by its atomic weight. In order to reflect chemical variations associated with climatic changes and the weathering of siliciclastic minerals, the $[\mathrm{Ca}]$ and $[\mathrm{CaO}]$ values used in the equation 3 and 4 were corrected for each samples to remove the effect of carbonate minerals using QEMSCAN analysis. WIP and CIA indexes were only calculated on one well where both elemental analysis and QEMSCAN data were available on the same samples (0/14-14-76-12W6). Furthermore, the sodium (Na) concentration was not measured on this well, but the impact of $\mathrm{Na}$ on these indexes is likely negligible based on its low concentration in other wells of this study (average of $0.8 \%$ in well 0/1617-83-25W6).

\section{RESULTS}

\subsection{Characterization of the organic content}

\subsubsection{Rock-Eval analyses}


Most of the studied samples have Rock Eval TOC values ranging between 0.25 and 1.75 wt\%, with a mean TOC of 1.28 wt\% (see figure 7). However locally, organic-rich intervals present TOC higher than $4 \mathrm{wt} \%$ in the Montney Fm. and can reach up to $13 \mathrm{wt} \%$ in the Doig phosphate zone (TST4). The wide range of Tmax (from 397 to $479{ }^{\circ} \mathrm{C}$ ) of our dataset is globally consistent with published vitrinite reflectance data (Rokosh et al. 2012; Romero et al., 2016) and suggests NE-SW increasing maturity trend from immature to overmature. The wide range of maturity may induce an under or over estimation of the in-situ TOC. Indeed, the dysmigration of the generated HC will lead to the underestimation of the TOC whereas the contamination by migrated $\mathrm{HC}$ will lead to the overestimation of the TOC. Rock-Eval pyrolysis results of the low maturity samples show that most of the $\mathrm{HI}$ values fall between 150 and $450 \mathrm{mgHC} / \mathrm{gC}$. This observation suggests that the OM found in the Montney and Doig Formations is mainly of Type II and Type III (figure 3).

Detailed analysis of Rock-Eval pyrograms shows that the S2 peak often presents a shoulder during the beginning of the temperature increasing (between $300^{\circ} \mathrm{C}$ and $450{ }^{\circ} \mathrm{C}$, figure 4). This shoulder can be interpreted in two different ways: there are two types of kerogen in the sample, or there is a presence of heavy hydrocarbons (Grundman et al., 2012). Figure 4 presents the pyrogram of both bulk-rock (BR) and extracted bulk-rock (eBR) samples. The analysis of both bulk-rock and extracted sample shows that the S2 is composed of both soluble and non-soluble OM, likely representing respectively heavy hydrocarbons and primary kerogen (figure 4). According to the work of Behar et al. (2008) and considering the low maturity of this sample ( $\operatorname{Tmax}=439{ }^{\circ} \mathrm{C}$ ), those heavy hydrocarbons may come from the early cracking of the kerogen.

\subsubsection{Palynofacies studies}

The investigated samples contain mainly AOM (figure 5). In the analyzed samples, only a small proportion of the OM derives from woody and terrestrial debris, regardless of the sedimentary facies ( $\mathrm{SP}$ and $\mathrm{PM}$ on figure $\mathbf{5} \mathrm{B}, \mathrm{C}$ and $\mathrm{I}$ ). The absence of damaged terrestrial $\mathrm{OM}$ showing a transformation 
from undamaged particles to AOM suggests that the AOM was more likely derived from marine rather than terrestrial sources (Tyson, 1995).

\subsection{Distribution of the organic content in the stratigraphic framework}

258

259

260

261

262

\subsubsection{TOC and $T O C_{i n i}$ in the stratigraphic framework}

The Rock-Eval results show that the two samples with the lowest maturity present high to moderate $\mathrm{HI}$ (respectively 549 and $373 \mathrm{mgHc} / \mathrm{gTOC}$ ). This is consistent with of a good Type II marine kerogen and a fair Type II/III kerogen. The palynofacies analyses paired with the Rock-Eval measurements suggest that regardless of the sedimentary facies, the AOM mainly derives from marine sources, typically having an initial $\mathrm{HI}\left(\mathrm{HI}_{\mathrm{ini}}\right)$ between 350 and $600 \mathrm{mgHC} / \mathrm{gTOC}$. These two values were used to compute a maximum and a minimum value of $\mathrm{TOC}_{\text {ini. }}$ In low maturity areas $\left(\mathrm{Tmax}<450^{\circ} \mathrm{C}\right.$ ), the computed $\mathrm{TOC}_{\mathrm{ini}}$ values likely reflect the initial organic content of the sediment. On the other hand, in more mature areas $\left(\operatorname{Tmax}>450^{\circ} \mathrm{C}\right), \mathrm{TOC}_{\text {ini }}$ computation can be affected by the secondary cracking of migrated oil. Figure 6 and 7 illustrate that sequence 3 and TST4 are the two main organic-rich intervals of this succession based on $\mathrm{TOC}_{\text {ini }}$ computation. In low maturity areas $\mathrm{TOC}_{\text {ini }}$ is close to present day TOC, whereas in more mature areas, $\mathrm{TOC}_{\text {ini }}$ can be up to twice as high as present day TOC (with $\mathrm{HI}_{\text {ini }}=600$ ).

The vertical distribution of TOC values within the stratigraphic framework highlight major differences between sequences (figure 6 and 7). Sequences 1 and 2 have low background present day TOC (respectively 1.3 and $0.9 \mathrm{wt} \%$ on average), with localized organic-rich intervals up to about $3 \mathrm{wt} \%$ (figure 7). Sequence 3 has higher background TOC (average of $2.2 \mathrm{wt} \%$ ) and fewer low TOC values (<1 wt\%) than sequence 1 and 2. TOC ${ }_{\text {ini }}$ values can reach up to 9 wt\% in LST3. The base of Sequence 4 is the richest interval in OM, with $\mathrm{TOC}_{\text {ini }}$ up to $14 \%$ (TST4=phosphate zone), but the rest of sequence 4 is organic-lean (average of $1.1 \mathrm{wt} \%$ ). The two main organic-rich intervals LST3 and TST4 show contrasting spatial distributions of the OM: 
In LST3, the organic content increase in the deeper central part of the basin at that time (offshore environment).

In TST4, TOC increase towards both margins of the basin (well 0/16-17-83-25W6 and 07-1474-06W6 on figure 6) while lower values are observed toward the axis of the basin (well

\subsubsection{Sedimentology of organic rich intervals}

285

286

287

288

289

290

291

In this section, we illustrate the sedimentological features of the organic-rich intervals of sequence 3 and 4. Figure 8 presents a synthetic sedimentary section from the sequence boundary 3 (SB3) up the maximum flooding surface 4 (MFS4). This interval dominantly consists of wave-dominated deposits, from offshore (bathymetry $\approx 200 \mathrm{~m}$ ) to shoreface depositional environments (figure $\mathbf{8}$, Crombez, 2016). In both sequences, organic-rich intervals correspond to offshore depositional environments. Sequence 3 presents a thick continuous interval of prograding deposits from offshore to lower shoreface (e.g. from 2380 to $2260 \mathrm{~m}$ on figure 8) whereas TST4 consists of thinly interbedded offshore and offshore transition deposits (e.g. from 2255 to $2240 \mathrm{~m}$ on figure 8). In sequence 3, the high TOC intervals are associated with pyrite and phosphate grains, but with only rare bioturbations (from 2380 to $2320 \mathrm{~m}$ on figure 8). In contrast, organic-rich layers in TST4 are associated with erosive lags, shell debris as well as pyrite and phosphate grains whereas bioturbations are present in the coarse-grained interbedded shallower deposits (from 2255 to $2240 \mathrm{~m}$ on figure 8). These differences suggest that the organic rich offshore deposits of TST4 are shallower than the offshore deposits of sequence 3

\subsubsection{Vertical and lateral variation of the sediment rates}

Sequence stratigraphic surfaces provide time lines across the basin (Crombez, 2016) and allowed for the computation of average sedimentation rates $(S R)$ in the studied intervals. The sequence $A$ was deposited during the lower Triassic (approximately $5 \mathrm{My}$ ) and the sequence B during the Middle Triassic (approximately $8 \mathrm{My}$ ). 
The figure 9 presents a cross-plot of the distribution of $\mathrm{TOC}_{\mathrm{ini}}$ versus the SR in the third order sequences along 8 sections. It shows that sequence B presents lower sedimentation rates $(S R<6$ $\mathrm{cm} / \mathrm{ka}$ ) than sequence $A(S R<16 \mathrm{~cm} / \mathrm{ka}$ ). More precisely it shows that sequences 1 to 3 present increasing average sedimentation rates (average SR from $4 \mathrm{~cm} / \mathrm{ka}$ to $12 \mathrm{~cm} / \mathrm{ka}$ ) whereas HST4 present lower sedimentation rates than TST4 (respectively average SR: $2 \mathrm{~cm} / \mathrm{ka}$ and $3 \mathrm{~cm} / \mathrm{ka}$ ). On figure 9, the sequences 1 and 2 present decreasing TOC $_{\text {ini }}$ concentration (from 3 to 0.2 wt\%) with increasing SR (from 16 to $4 \mathrm{~cm} / \mathrm{ka}$ ). The sequence 3 presents a similar evolution but with a steepest trend ( $\mathrm{TOC}_{\text {ini }}$ from 7 to $3 \mathrm{wt} \%$ and SR from 12 to $16 \mathrm{~cm} / \mathrm{ka}$ ). The TST4 does not present a clear relation between $\mathrm{TOC}_{\text {ini }}$ accumulation and SR. On one side, the figure 9 presents high $\mathrm{TOC}_{\text {ini }}$ (up to 15 wt\%) associated with the highest SR of the TST4 $(4 \mathrm{~cm} / \mathrm{ka})$ and on the other side it shows decreasing TOC $_{\text {ini }}$ (from 2.5 to 0 wt\%) with increasing SR (from 1 to $2 \mathrm{~cm} / \mathrm{ka}$ ). Lastly HST4 presents an increasing then decreasing $\mathrm{TOC}_{\mathrm{ini}}$ (from 1 to $2.5 \mathrm{wt} \%$ then from 2.5 to $0 \mathrm{wt} \%$ ) with increasing SR (from 0.3 to 4 $\mathrm{cm} / \mathrm{ka})$.

Tyson (2001) highlighted the impact of SR on OM accumulation. On one side, this study showed that, in oxic environments, a range of SR (from 2 to $20 \mathrm{~cm} / \mathrm{ka}$ ) is increasing OM preservation. In oxic intervals, the impact of the SR results in an increasing then decreasing TOC concentration with a maximum accumulation above $5 \mathrm{~cm} / \mathrm{ka}$. The cross-plots of sequences 1,2 and of the HST4 highlight the direct impact of organic particles dilution: sequences 1 and 2 only present the decreasing TOC $_{\text {ini }}$ whereas the HST4 presents both the increasing and decreasing trends linked to the ideal sedimentation rates interval. On the other side, in anoxic environments the preservation of the organic matter is assured and an increasing SR will only decrease the TOC (Tyson, 2001). The rapid increase of the $\mathrm{TOC}_{\text {ini }}$ in the Seq 3 and the complex relation between $\mathrm{TOC}_{\text {ini }}$ and SR in TST4 suggest that organic matter accumulation in TST4 and sequence 3 is not solely controlled by the dilution but by a complex combination of primary productivity, preservation and dilution.

\subsection{Trace metal element variations}


330

331

Organic productivity can be studied through several proxies, including $\mathrm{Cu}$ and $\mathrm{Ni}$ which are micronutrients assimilated by the micro and macro-organisms (Calvert and Price, 1983; Calvert and Pedersen, 1993; Whitfield, 2001; Brumsack, 2006; Tribovillard et al., 2006; Schoepfer et al., 2014). In the present study, the vertical evolution of $\mathrm{Ni} / \mathrm{Al}$ and $\mathrm{Cu} / \mathrm{Al}$ are chosen to reflect the variations of nutrients input in the basin which may be associated with primary organic productivity variations (Whitfield, 2001; Brumsack, 2006; Tribovillard et al., 2006)

The figure 10 presents a cross-plot of the EF of $\mathrm{Cu}$ vs $\mathrm{Ni}$ at four different locations in the basin. In this figure, most of $\mathrm{EF}$ of $\mathrm{Cu}$ and $\mathrm{Ni}$ are higher than 1. In comparison to black shale (Cretaceous and present day, Brumsack, 2006) the EF of $\mathrm{Cu}$ and Ni remain low in the Montney and Doig Formations. TST4 shows the highest EF in sections 0/16-17-83-25W6 section $(3<E F(N i)<10 ; 2<E F(C u)<30)$ and 0/14-14-76-12W6 $(\mathrm{EF}(\mathrm{Ni}) \approx 10 ; \mathrm{EF}(\mathrm{Cu}) \approx 2.5)$. In these wells, samples with High TOC always have high EF, however high EF does not automatically imply high TOC. No simple linear relation exists between $\mathrm{EF}(\mathrm{Ni})$ or $\mathrm{EF}(\mathrm{Cu})$ and $\mathrm{TOC}$.

The figure 11 presents the vertical evolution of $\mathrm{Cu} / \mathrm{Al}$ and $\mathrm{Ni} / \mathrm{Al}$ along the four sections. In these sections, $\mathrm{Cu} / \mathrm{Al}$ ranges from $3.10^{-4}$ to more than $30.10^{-4}$ whereas $\mathrm{Ni} / \mathrm{Al}$ ranges from $5.10^{-4}$ to $55.10^{-4}$.

0/16-17-83-25W6:

In sequences 1 and 2 , both ratios show little variations and stay low $(\mathrm{Cu} / \mathrm{Al} \approx 5.10-4$ and $\mathrm{Ni} / \mathrm{Al} \approx$ 7.5.10-4), slightly higher than the Upper crust average $(\mathrm{Cu} / \mathrm{Al}=3.1 \cdot 10-4$ and $\mathrm{Ni} / \mathrm{Al}=5.5 \cdot 10-4)$. Sequence 3 records a small increase in $\mathrm{Cu} / \mathrm{Al}$ (from 5.10-4 to 6.10-4) and in Ni/Al (from 7.5.10-4 to 11.10-4). In contrast, sequence 4 shows high $\mathrm{Ni} / \mathrm{Al}$ and $\mathrm{Cu} / \mathrm{Al}$ ratios $(\mathrm{Cu} / \mathrm{Al}>20.10-4$ and $\mathrm{Ni} / \mathrm{Al}>$ 25.10-4). These higher concentrations of $\mathrm{Cu}$ and $\mathrm{Ni}$ in TST4 are associated with high TOC value. 
352

353

354

355

356

357

358

359

360

361

362

363

364

365

366

367

368

369

370

371

372

373

374

375

376

In this section, TST4 shows a strong increase of Ni/Al ratio from $7.5 .10^{-4}$ to $50.10^{-4}$ and a slight increase of $\mathrm{Cu} / \mathrm{Al}$ ration from $5.10^{-4}$ to $9.10^{-4}$. No other significant variations are present along this section $\left(\mathrm{Cu} / \mathrm{Al} \approx 5.10^{-4}\right.$ and $\left.\mathrm{Ni} / \mathrm{Al} \approx 7 \cdot 5 \cdot 10^{-4}\right)$.

0/06-33-72-25W5:

This section shows low values for both $\operatorname{ratios}\left(\mathrm{Cu} / \mathrm{Al} \approx 5.10^{-4}\right.$ and $\left.\mathrm{Ni} / \mathrm{Al} \approx 7.5 .10^{-4}\right)$, consistent with a more proximal depositional setting dominated by detrital inputs.

\section{Brown Hill:}

In sequences 1 and 2, the low $\mathrm{Cu} / \mathrm{Al}$ and $\mathrm{Ni} / \mathrm{Al}$ (respectively $6.10^{-4}$ and $8.10^{-4}$ ) are punctuated by peaks of higher $\mathrm{Cu} / \mathrm{Al}$ (up to $22.10^{-4}$ ). Along this section, the highest peaks of both ratios are not linked to an important concentration of $\mathrm{Ni}$ and $\mathrm{Cu}$ but to a very low concentration of $\mathrm{Al}$, it is therefore an artifact of normalization.

Interpretation:

On the four sections, the only significant increase in $\mathrm{CU} / \mathrm{Al}$ and $\mathrm{Ni} / \mathrm{Al}$ ratios occurs during TST4, suggesting a strong increase in organic paleoproductivity during this interval. High amplitude variations of both ratios in this interval also highlight cyclic fluctuations of paleoproductivity during TST4. It is important to note that the increase of the authigenic Ni and Cu occurred after a sharp drop of the sedimentation rates across the boundary between sequence A and B. Even though HST4 present low $\mathrm{Ni} / \mathrm{Al}$ and $\mathrm{Cu} / \mathrm{Al}$ ratios, the influence of low sedimentation rates on TST4 enrichment cannot be ruled out. However, it is also worth noting that both $\mathrm{Cu}$ and $\mathrm{Ni}$ concentrations are positively correlated to Al during sequence $A$, whereas no such relations were observed in TST4. This evidence supports the hypothesis of a change of nutrient source between sequence $A$ and $B$, with an increase of primary productivity during TST4. In sequence 3 , the small increase of $\mathrm{Ni}$ and $\mathrm{Cu}$ concentration can be either linked to a small increase of the primary productivity or to a better preservation of the OM (confirmed by U/Th and Mo/Al proxies) at the water sediment interface that will induce a lower recycling of the nutrients included in the OM (Riquier et al., 2005). 


\section{ACCEPTED MANUSCRIPT}

\subsubsection{Uranium (U), Molybdenum (Mo) and Vanadium (V) variations}

Some trace elements present in the water are sensitive to redox condition (e.g. U, Mo, V and Ce) and provide information on the oxygen and sulfur content in the water at the time of the deposition (Emerson and Huested, 1991; Calvert and Pedersen, 1993; Crusius et al., 1996; Brumsack, 2006; Algeo and Lyons, 2006; Tribovillard et al., 2006; Algeo and Tribovillard, 2009).

The figure 12 presents a cross-plot of the $\mathrm{U} / \mathrm{Th}$ and $\mathrm{V} / \mathrm{Cr}$ ratios from four different sections across the basin. In these ratios, the redox-sensitive elements ( $\mathrm{U}$ and $\mathrm{V})$ are normalized to $\mathrm{Th}$ and $\mathrm{Cr}$ which are both assumed to be linked to detrital inputs. These ratios therefore present the authigenic variation of $U$ and $V$ that are linked to anoxic episodes. These cross-plots show a link between the ratios and the TOC content along wells $0 / 16-17-83-25$ W6 and 0/14-14-76-12W6: samples with high ratios present the highest TOC. These cross-plot also show that sequence 1 and 2 present higher oxygen content $(\mathrm{U} / \mathrm{Th}<0.75$ and $\mathrm{V} / \mathrm{Cr}<2)$ than sequence 3 and part of sequence 4 (most of $\mathrm{U} / \mathrm{Th}>0.75$ and $\mathrm{V} / \mathrm{Cr}>2)$.

The figure 13Error! Reference source not found. presents the vertical evolution of U/Th and Mo/AI along four sections. In the four sections, $\mathrm{U} / \mathrm{Th}$ ranges from 0.3 to 4.5 whereas the Mo/Al ranges from $1.10^{-4}$ to $24 \cdot 10^{-4}$.

0/16-17-83-25W6:

From SB1 up to MFS2, both ratios stay low $\left(\mathrm{U} / \mathrm{Th} \approx 0.3 \mathrm{and} \mathrm{Mo} / \mathrm{Al} \approx 1.10^{-4}\right)$. The interval between MFS2 and SB3 shows an increase, then a decrease of $U / T h$ and Mo/Al ratios (U/Th: from 0.3 up to 1.25 down to 0.3 and Mo/Al: from $1.10^{-4}$ up to $7.5 .10^{-4}$ down to $1.10^{-4}$ ). In sequence 3 the interval presents moderate $\mathrm{U} / \mathrm{Th}(>0.75)$ and high $\mathrm{Mo} / \mathrm{Al}\left(>5.10^{-4}\right)$ that seems to oscillate with no correlation with the transgressive and regressive trends of the sedimentary system. Lastly in the TST4, U/Th and Mo/Al both show significant increases (U/Th: from 0.3 up to 4.5 ; Mo/Al: from $2.10^{-4}$ up to $25.10^{-4}$ ). 
Along this section, $\mathrm{U} / \mathrm{Th}$ and $\mathrm{Mo} / \mathrm{Al}$ mainly present low values $\left(\mathrm{U} / \mathrm{Th}<0.75\right.$ and $\mathrm{Mo} / \mathrm{Al}<5.10^{-4}$ ) except in the TST4 where both ratios increase significantly (up to $\mathrm{U} / \mathrm{Th} \approx 2.25$ and $\mathrm{Mo} / \mathrm{Al}<15.10^{-4}$ ).

0/06-33-72-25W5:

On this section no significant increase of both ratios are present $\left(\mathrm{U} / \mathrm{Th}<0.75\right.$ and $\left.\mathrm{Mo} / \mathrm{Al}<5.10^{-4}\right)$

Brown Hill:

As for the 0/06-33-72-25W5, both proxies along Brown Hill section show very low values. The only high values of both ratios are linked to very low concentration of Al or Th.

\section{Interpretation:}

Figures 12 and 13 present sedimentary records of redox sensitive elements. These figures suggest that the water column was oxic to dysoxic during sequence 1 and 2 . In sequence 2 , the small increase then decrease of the $\mathrm{U} / \mathrm{Th}$ and Mo/Al ratios is interpreted as the development of small anoxic puddle in the deepest part of the basin. Above SB3, redox sensitive trace elements suggest variations of $\mathrm{O}_{2}$ concentrations in the water column and the occurrence of dysoxic to anoxic layers in the deepest part of the basin (located near the well 0/16-17-83-25W6 at that time). In this sequence, the high concentration of Mo suggests that water/sediment interface may contain $\mathrm{H}_{2} \mathrm{~S}$ (Jones and Manning, 1994). In sequence 4, due to the geodynamic evolution and the changes in the basin physiography, the well 0/16-17-83-25W6 present more proximal deposits. In the TST4, the high U/Th and Mo/Al ratios show the occurrence of anoxic to euxinic conditions. In this interval, $\mathrm{O}_{2}$-depleted and possible $\mathrm{H}_{2} \mathrm{~S}$ enriched conditions took place along the more proximal areas. As already mentioned for $\mathrm{Ni} / \mathrm{Al}$ and $\mathrm{Cu} / \mathrm{Al}$ ratios, the drop of sedimentary fluxes across the boundary between sequence $\mathrm{A}$ and $\mathrm{B}$ may influence the dilution of authigenic molybdenum and uranium. However, when corrected from dilution effect based on computed sedimentation rates (dilution 4 times lower in sequence B compared to sequence A), U/Th and Mo/Al ratios are still characteristic of anoxia (respectively 1 and $\left.5.10^{-4}\right)$

\subsubsection{Molybdenum (Mo) and TOC variations}


Changes in basin restriction can be investigated thanks to molybdenum and TOC covariations. Figure

14 presents molybdenum versus TOC cross-plot along four sections. On these cross plots, TOC values range from 0 to $15.2 \mathrm{wt} \%$, with the maximums located in the sequence 4 and, the molybdenum concentration ranges from 0 to $101.6 \mathrm{ppm}$ with the maximums located in the sequence 3 . The TOC and Mo concentrations from wells 0/14-14-76-12W6 and 0/06-33-72-25W5 and from Brown Hill outcrop stay very low (TOC $<3 w t \%$ and Mo $<25$ ) except for two cutting samples located near SB3 and SB4. Mo and TOC covariations in different restricted basins (the Saanich inlet, the Cariaco basin, the Framvaren fjord and the Black sea, respectively $\mathrm{SI}, \mathrm{CB}, \mathrm{FF}$ and $\mathrm{BS}$ on figure 14) are presented by Algeo and Lyons (2006). All the low TOC and Mo samples of the present cannot be related to one of these case studies. The samples of well 16-17-83-25W6 present more significant results with moderate to high TOC and molybdenum concentration $(1.5<\mathrm{TOC}<15.2 \mathrm{wt} \%$ and $0<$ Mo $<101.6$ ppm). Along this well, values for sequences 1 to 3 fall between the Cariaco basin trend and the Black sea trend, whereas sequence 4 values clearly fall along the Black sea trend.

In restricted basin, due to low water and molybdenum reservoir renewal, the Mo/TOC ratio generally stays low $(<15)$ whereas in open marine settings, due to the water circulation, the Mo/TOC ratio is relatively high (>60). The cross-plots of figure 14 show that regardless of the well and the sequence, samples always presents relatively low Mo/TOC ratios $(<35)$ which tend to highlight a moderately to highly restricted basin (Algeo and Lyons, 2006). The cross-plots of 0/14-14-76-12W6, 0/06-33-7225W5 and Brown Hill sections are consistent with figure 13: anoxia proxies (U/Th, V/Cr and Mo/Al) do not highlight major anoxic event along those three sections excepted in the early sequence 4 of the 0/14-14-76-12W6 well which induced a low concentration of Mo. Along the well 0/16-17-83$25 \mathrm{~W} 6$, the interpretation of the basin restriction evolution between sequence $A$ and sequence $B$ must be done with caution: firstly only some intervals of sequence 3 and the TST 4 present anoxia. Secondly, the significant drop of the sedimentary supply across the boundary between sequence 3 and 4 (see figure 9) may also impact the concentration of Mo and the TOC. In order to remove this 
sedimentary supply decrease between sequence $A$ and $B$, Crombez, 2016). This correction puts the sequence 4 samples in the lower left side (with sequences 1 and 2) of the cross plot in an area where a restriction is uncertain. All these observation tends to show that both sequence $A$ and $B$ were deposited in a restricted basin, that may be more restricted in sequence 3 that in the other sequences.

\subsubsection{Weathering index of Parker (WIP) and chemical alteration index (CIA) variations}

Figure 15 presents a cross-plot of the WIP and CIA along the 0/14-14-76-12W6. On this figure, the WIP ranges from, 20 to 80 but most of the samples are comprised between 35 and 50 whereas the $\mathrm{CIA}$ ranges from 45 to 85 . This figure does not show any maturity trend along the four sequences. Sediment maturity trend are likely to reveal climatic evolution of an area (Parker, 1970; Nesbitt and Young, 1982; Bahlburg and Dobrzinski, 2011), the cross plot presented in figure 15 suggests that no major climatic changes took place over the western Canada sedimentary basin during the Lower and Middle Triassic.

\section{DISCUSSIONS}

In the following section, we discuss the source of $\mathrm{OM}$ in the Montney and Doig Formations, the spatial and temporal variations of controlling factors on the accumulation and preservation of this $\mathrm{OM}$ and finally, their relationship with relative sea level variations and the basin physiography.

\subsection{Organic matter in the Montney and Doig Formations}

Rock-Eval analyses show that the OM in the Montney and Doig Formation represents Type II/III source rocks (figure 3), which is consistent with the studies of Riediger et al. (1990) and Riediger (1997). In the Montney and Doig Formations, two intervals present significant enrichment in OM: the sequence 3 (Upper Montney) and the TST4 (Doig phosphate) which is also consistent with previous studies (Ibrahimbas and Riediger, 2004). 
Our Rock-Eval analyses data on extracted, low maturity samples, confirm the presence of kerogen in the studied samples (figure 4) whereas palynomorphs analyses (figure 5), show that this primary OM derives from planktonic sources. Lastly, the analysis of trace elements shows the occurrence of $\mathrm{Cu}$, $\mathrm{Ni}, \mathrm{U}$ and Mo enrichments in the Montney and Doig Formations. In the present work, these enrichments are interpreted to be linked to redox conditions and/or primary productivity variations (Tribovillard et al., 2006). As crude oil contains important concentration of trace metal elements (Lord, 1991; Duyck et al., 2002), the enrichments that are highlighted in sequence 3 could also be linked to bitumen associated with secondary cracking of migrated oil. In the present study, we were unable to establish a clear relation between TOC concentration and the trace metal element concentrations, or the Al-normalized concentration of those elements and the TOC. It is therefore unlikely that all the organic content in the Montney Formation comes from migrated hydrocarbons.

In the present work, the study of Rock-Eval S1 values does not allow for the recognition of good conventional reservoir intervals. In the Montney and Doig Formations, average S1 value is low $(<0.4$ $\mathrm{mgHC}$ (gRock) and high S1 values within low maturity areas, which correspond to good conventional reservoir, are absent. Recent works of Sanei et al. (2015) and Wood et al. (2015) concluded that most of the organic content in the Montney Formation derives from migrated hydrocarbons. In their studies, the most part of the organic content in the Montney Formation is considered to be pyrobitumen, resulting from the secondary cracking of migrated oil. Regarding the low maturity (Tmax $<450$ ) of the primary organic matter in some part of the basin and the very low permeability of the Montney and Doig Formation ( $<0.01 \mathrm{mD}$, Chalmers and Bustin, 2012), it is unlikely that the organic matter is coming from the secondary cracking of a migrated bitumen (due to the le permeability) or from the secondary cracking of a light oil (due to the low thermic maturity). Our study does not question the presence of pyrobitumen in the Montney-Doig Formations, but it also emphasizes the occurrence of primary kerogen in this interval. Analysis of the elementary proxies shows that the sequence 3 and part of sequence 4 present propitious redox conditions and primary productivity for source rocks development, whereas sequences 1 and 2 present less conductive 
conditions to organic rich sediment accumulation (figure 10 to 13). Estimating the relative proportion of migrated versus in place hydrocarbons in the Montney Formation is beyond the scope of the present study and would necessitate a quantitative basin analysis.

\subsection{Spatial variations and temporal evolution of primary productivity, anoxia and dilution} and their impacts on organic matter distribution

Recent works (Sageman et al., 2003; Bohacs et al., 2005; Katz, 2005) showed that the organic richness of sedimentary rocks is controlled by a combination of three mains factors: (1) the primary organic production by flora and fauna, (2) its dilution by non-hydrogenated particles and (3) its preservation. Bohacs et al. (2005) showed that a high productivity combined with a low dilution rates is not the most efficient way to produce and preserve an organic rich rock. Indeed, an extremely high planktonic productivity will dilute the organic content in the tests of the micro-organisms and a low SR will minimize the burial efficiency and will allow a higher bacterial degradation and oxidation at the water sediment interface and therefore lead to weak preservation.

In the present study, the palynofacies analyses mostly revealed AOM coming from marine planktonic faunas. In a sedimentary basin, the OM can be degraded or destructed by various processes occurring in the water column and in the first centimeters below the water-sediment interface (Demaison and Moore, 1980; Southam et al., 1982; Einsele, 1992; Calvert et al., 1996): (1) In the production areas, the OM produced by micro-organisms can be consumed and recycled by macroorganisms (Eppley and Peterson, 1979). However assuming that the macro organisms also produce $\mathrm{OM}$, this phenomenon only has a small impact on the total OM production. (2) While settling through the water column, the $\mathrm{OM}$ can be oxidized and therefore degraded by the oxygen present in the water (Karl et al., 1988; Wakeham and Lee, 1993). Therefore, at a constant production rate, the OM is better preserved in anoxic or dysoxic water (Cowie and Hedges, 1992; Canfield, 1993). However, if production is high enough, sinking OM consume all the oxygen leading to the creation of Oxygen Minimum Zone (OMZ) and the preservation of the remaining OM (Southam et al., 1982; Einsele, 
1992; Paulmier and Ruiz-Pino, 2009). (3) In the first centimeter below the water/sediments interface, rapid degradation of the $\mathrm{OM}$ takes place as long as oxygen is present. The occurrence of macroorganism in oxic sediments results in bio-degradation of the OM present in the sediments (Ingall et al., 1993). Most of OM degradation will stop a few centimeters below the water/sediments interface due the depletion in oxygen in the buried layers (Wenzhofer and Glud, 2002). Globally, the preservation of $\mathrm{OM}$ is highly linked to the oxygen content in the water and sediments.

\subsubsection{Basin scale variations of primary productivity, anoxia and dilution}

The relative contribution of the three main factors (production-dilution-preservation) controlling initial TOC of sediment can be estimated by integrating sequence stratigraphy interpretation with trace element analysis. Based on trace elements analyses from wells 0/16-17-83-25W6; 0/14-14-7612 W6 and 0/06-33-72-25W5 and based on the Rock-Eval analyses of five additional wells, the figure 16 presents an interpretation of the vertical and the lateral variations of the factors that drive organic richness in sedimentary rocks. It confirms that there is no simple relation between SR (dilution) and the organic content in the studied interval. Tyson (2001) concluded that SR close to 5 $\mathrm{cm} / \mathrm{ka}$ may enhance the concentration of the OM which is observable in sequence 1, 2 and the HST4

\section{(figure 9).}

On the figure 16, it is apparent that local OM enrichment occurs near MFS or parasequence flooding surfaces, similar to trends observed by Creaney and Passey (1993). However, a low SR alone cannot explain the organic enrichment of condensed layer, indeed low burial efficiency resulting from a low SR will promote the degradation of OM (Tyson, 2001; Bohacs, 2005; Katz, 2005). In the studied interval, small increases of anoxia proxies are commonly associated with organic rich intervals, suggesting occurrence of small anoxic puddles, most likely linked to basin floor physiography. Local and punctual enrichment would therefore be linked to a combination of starved intervals and local anoxic layers (Algeo and Rowe, 2012). 
Figure 16 illustrates that low to moderate organic productivity, mainly oxic water (85\% of the U/Th ratio $<0.75$, Jones and Manning, 1994) and high sedimentation rates prevailed during sequence 1 and 2, regardless of the position along the depositional profile. In this interval, rare TOC peaks are present and are interpreted to be associated with either local dysoxic to anoxic episodes (U/Th ratio increase) or punctual decrease SR (e.g. near MFS). Above sequence 1 and 2, figure 16 shows a major change in the paleo-redox conditions. At that time the oxic to dysoxic water of sequence 2 turns into dysoxic to anoxic water marked by an increase of $\mathrm{U} / \mathrm{Th}$ and Mo/Al ratios (Emerson and Huested, 1991; Tribovillard et al., 2004; Brumsack, 2006). These anoxic conditions are clearly present in the deepest part of the basin, in offshore facies and are weaker in the shoreface facies on the edges on the basin (figure 16). This major change of the water's oxygen content is not interpreted to be associated with an important variation of primary productivity. Indeed, the small increases in $\mathrm{Cu} / \mathrm{Al}$ ratio observed on the $0 / 16-17-83-25 \mathrm{~W} 6$ are interpreted to be linked to the better preservation of the OM (Riquier et al., 2005). In sequence 3, the organic-rich deposits are located in the central part of the basin where oxygen content is minimum (figure 16). In this interval, the fluctuation of anoxic conditions are associated with the progradation and backstep of the depositional system.

Above this anoxic episode, the figure $\mathbf{1 6}$ shows for the first time an important increase of primary productivity associated with anoxic water marked by important increase of $\mathrm{Cu} / \mathrm{Al}, \mathrm{Ni} / \mathrm{Al}, \mathrm{U} / \mathrm{Th}$ and Mo/Al ratios (Tribovillard et al., 2004; Algeo and Lyons, 2006; Tribovillard et al., 2006). In this interval, organic rich deposits are located in periphery of the basin. Unlike in sequence 3, anoxia is strongest at the edges of the basin and alternate with dysoxic periods, suggesting the onset of an $\mathrm{OMZ}$, triggered by the high primary productivity at sea surface. Above the MFS4, the basin returns to similar conditions as in sequence 1 and 2: low to moderate productivity and high oxygen content in the water, leading to low production and poor preservation of OM (figure 16).

\subsubsection{Models for organic-rich rocks deposition}


In this study, we highlight four main stages characterized by contrasted depositional dynamics that result in different temporal and spatial distributions of $\mathrm{OM}$ in the basin:

- Sequence 1 and 2: oxic water and low paleoproductivity.

- Sequence 3: dysoxia/anoxia takes place in the deepest part of the basin.

- TST4: the anoxia is associated with an increase of paleoproductivity on the basin margins.

- Above MSF4, the basin returned to its initial condition: oxic water associated with a low productivity.

Based on these observations we propose a model for the deposition of the organic-rich layer in the Montney and Doig Formations (figure 17). These models split the investigated interval in 3 conceptual basin types: Type 1: an oxic basin, that prevailed during sequence 1 and 2 and HST4. Type 2: a restricted basin that is representative of the sequence 3 . Type 3 : a high primary productivity basin that is diagnostic of the TST4.

During sequence 1,2 as well as HST4, the low primary productivity along the coast, the high oxygen content in the water lead to limited organic accumulation in the basin (figure 16 and 17 A).

In sequence 3 , a restriction of the connection between the open marine settings and the basin due to low relative sea level induced a decrease of water circulation and therefore a stratification of the water column that to the development of anoxia in the deepest part of the basin (figure 16 and 17 B, Demaison and Moore, 1980; Huc, 1988; Arthur and Sageman, 1994; Brumsack, 2006; Algeo et al., 2008; Algeo and Rowe, 2012). The stratification is supposed to take place below the storm weather wave base (SWWB) where water mixing is limited. This stratification associated with a primary productivity similar to sequence 1 and 2 allows for the preservation of produced OM transported in the deepest part of the basin. On the edges of the basin, where the bathymetry does not go below the SWWB, OM is poorly preserved (figure 16).

This study highlighted an increase in primary productivity and the occurrence of anoxic water along the margin of the basin In the TST4 (figure 16 and 17 C, Demaison and Moore, 1980; Calvert and Price, 1983; Emeis et al., 1991; Wignall and Newtown, 2001; Brumsack, 2006; Algeo et al., 2008). This 
600

601

602

603

604

605

606

607

608

609

610

611

612

613

614

615

616

617

618

619

620

621

622

623

productivity, associated with the anoxia controlled the preservation of very rich organic layers on the edges of the basin. In this systems tract, anoxic condition and increased productivity were also highlighted in the central part of the basin, but with a lower intensity than on the edges of the basin.

The integration of geochemical analyses in the stratigraphic framework highlighted three different types of basin in the studied interval. Those three types of basin present drastically different distribution of OM due to differences in dynamic of anoxia and primary productivity.

Sequence stratigraphy study shows that the deposition of the Montney and Doig Formations most likely took place in an oval shaped basin between the proto-cordillera and the western margin of Pangea (Crombez, 2016; Rohais et al., 2016). In these settings, OM is poorly preserved in type 1 basin (figure 17 A). In a type 2 basin (figure 17 B), organic rich deposits are located in the central part of the basin where the oxygen content is minimum. This type of basin is very similar to the present-day Black Sea where the production of the OM takes place along the margin of the basin and OM is accumulated in the central part of the basin (Huc, 1988; Wilkin et al., 1997; Arthur and Dean, 1998; Algeo and Lyons, 2006; Algeo et al., 2008). In this type of basin, the organic rich area will likely be round-shaped in the deep basin. Lastly, in a type 3 basin (figure $\mathbf{1 7} \mathrm{C}$ ), the organic-rich layers are located below the production areas, where the oxygen content is minimum due to the development of OMZ. As the production areas can be considered a function of the distance to the shore (Calvert, 1987; Baudin et al., 2007), the organic rich areas resulting from this type of basin are likely to be halo-shaped parallel to the shoreline.

\subsection{Controls on primary productivity and anoxia}

Our analysis suggest that during the Lower and Middle Triassic in Western Canada, the evolution of primary productivity and anoxia through time was associated with major stratigraphic surfaces (figure 16). In particular, physiographic changes of the basin across the boundary between thirdorder sequence 2 and 3 as well as between second-order sequence $A$ and $B$ (Crombez, 2016) appear 
to have a major impact on the distribution of organic matter. These changes likely reflect the early geodynamic evolution of the Canadian Cordillera.

\subsubsection{Primary productivity}

A strong increase of primary productivity occurred during TST4, above a major erosional unconformity that modified the physiography of the basin. Several models explain the increase of organic productivity by an augmentation of nutrients inputs from the continent due to climate enhanced continental weathering (Algeo et al., 2008) or associated with a marine transgression (Wignall and Newton, 2001). Other studies explain the increase of primary productivity by the input of deep marine nutrients associated with upwelling cells (Heckel, 1977; Demaison and Moore, 1980; Calvert and Price, 1983; Emeis et al., 1991).

During sequence $A$, the positive correlation of detrital supply proxies (Al) with organic productivity proxies $(\mathrm{Ni}, \mathrm{Cu})$ suggests that nutrients were supplied by the continent and their low concentration resulted in low to moderate organic productivity in the Montney Formation. During TST4, such a relation between detrital input and organic productivity was not observed, suggesting another source of nutrients. A recent study (Krajewski, 2013) on Triassic strata from Svalbard archipelago, shows that the increase of primary productivity in the basin is mainly controlled by the stratigraphic evolution that establish the connection between upwelling cells and a moderately restricted basin (figure 14). A major change of basin physiography across the boundary between sequence $A$ and $B$, associated with the early geodynamic evolution of the foreland basin might have resulted in the connection with upwelling cells present during the Triassic along the NW margin of Pangea (Parrish and Curtis, 1982). Accordingly, the increase of nutrients delivery during TST4 is probably linked to a combination of the transgressive trend and the regional geodynamic evolution that connect the basin with upwelling cells.

\subsubsection{Anoxia}


Anoxia in sedimentary basin is mainly driven by two processes: the basin restriction (e.g. the Black Sea, Demaison and Moore, 1980; Huc, 1988; Arthur and Sageman, 1994; Brumsack, 2006; Algeo and Rowe, 2012) and the primary productivity (e.g. the Peruvian Margin, Demaison and Moore, 1980; Arthur and Sageman, 1994; Emeis et al., 1991; Calvert and Price 1983; Arthur and Dean, 1998; Brumsack, 2006; Paulmier and Ruiz-Pino, 2009).

The Montney and Doig Formations present two intervals of anoxia during sequence 3 and TST4. The anoxia in sequence 3 is associated with a moderate to low productivity and a major falling stage of relative sea level whereas TST4 is a second order transgressive period associated with increased primary productivity.

During sequence 3 , the lowstand relative sea level lead to restricted connections between the basin and the open marine settings and resulted in reduced water exchange between the two domains and a stratification of the water column. In this setting, the anoxia in the basin is controlled by both the physiography of the basin and the stratigraphic settings that allow for the occurrence of a threshold area.

In the TST4, the high primary productivity triggered the development of an oxygen minimum zone directly below the production area. Unlike in sequence 3, the anoxia in TST4 was controlled by the primary productivity, although the additional impact of basin restriction on anoxia is difficult to estimate.

In the Montney and Doig Formations, the two anoxic episodes present different extension and dynamic. (1) The anoxic episode at the upper part of the Montney Formation was mainly linked to the physiography of the basin and to its stratigraphic evolution. (2) The anoxic areas in TST4 were likely controlled by organic productivity and therefore were not located in the center of the basin but instead in halo-shaped belts associated with up-welling cells. Further work involving forward stratigraphic modeling would help addressing the relative impact of primary productivity versus basin restriction on the resulting anoxia. 


\section{CONCLUSIONS}

674

675

676

677

678

679

680

681

682

683

684

685

686

687

688

689

690

691

692

693

694

695

696

697

The work presented in this paper is based on well and outcrop data. It integrates geochemical analyses in a stratigraphic framework in order to understand the distribution of organic-rich layers in a sedimentary basin and the dynamic of the key controlling factors: primary productivity, dilution and preservation of OM at basin scale. This multidisciplinary study shows:

- The occurrence of primary OM in the Montney and Doig Formations. The palynofacies analyses reveal the occurrence of planktonic OM (figure 5).

- The need for a large scale sequence stratigraphic framework to understand local variation of $\mathrm{OM}$ accumulation. In the studied interval, the time lines provided the opportunity to understand the major spatial and temporal changes of organic primary productivity and redox conditions.

- The impact of these variations of redox conditions and productivity on the vertical distribution of OM in the Montney and Doig Formations. Sequences 1 and 2 present low TOC content, whereas sequence 3 and TST4 present some organic-rich accumulations. This complex distribution is linked to the development of a "Restricted basin" in sequence 3 and a "High primary productivity basin" in the TST4.

- The lateral variation of OM content due to different rates of productivity and different types of anoxia. In a "High primary productivity basin", the organic rich layers are located along the coast below the production areas whereas, in a "Restricted basin", the organic rich layers is deposited in the center basin.

- The occurrence of two different types of anoxia. In the Montney Formation, sequence 1 and 2 may show small episodic "Restricted basins" (ponds) in the basin center and the sequence 3 can be considered as a large "Restricted basin" (figure 17 B). In the TST4, the anoxia is located along the basin margin ("High primary productivity basin", figure $17 \mathrm{C}$ ). In the Montney Formation, the anoxia is induced by the physiography of the basin and by 
the sea level falling stage whereas in the Doig phosphate unit, the anoxia is linked to organic primary productivity associated with a second order transgressive trend induced by major geodynamical changes.

- The primary controls of the basin physiography and stratigraphic settings on anoxia. In the studied interval, the "Restricted basin" is the result of a major sea level falling stage in a threshold basin whereas the "High primary productivity basin" is linked to a major transgressive interval. In the present study, the threshold is linked to the proto-Canadian Cordillera accretion and induces strong restriction.

- The second order transgressive periods do not always present high organic accumulation.

- In our case study anoxia and primary productivity are the two main controls on organic richness, while dilution as only a marginal impact.

\section{ACKNOWLEDGEMENTS}

Acknowledgments go to all those who have contributed to this project: IFP Technologies (Canada) Inc., SGS Canada, Alberta Energy regulator and the Geological Survey of Canada. Special acknowledgments go to M.F. Romero Sarmiento, J. Letord, F. Savignac for their help during sample analysis and to Schlumberger that provided Petrel academic licenses.

\section{REFERENCES}

Algeo, T.J., Tribovillard, N., 2009. Environmental analysis of paleoceanographic systems based on molybdenum-uranium covariation. Chemical Geology 268, 211-225. doi:10.1016/j.chemgeo.2009.09.001

Algeo, T.J., Lyons, T.W., 2006. Mo-total organic carbon covariation in modern anoxic marine environments: Implications for analysis of paleoredox and paleohydrographic conditions. Paleoceanography 21, n/a-n/a. doi:10.1029/2004PA001112

Algeo, T.J., Rowe, H., 2012. Paleoceanographic applications of trace-metal concentration data. Chemical Geology 324-325, 6-18. doi:10.1016/j.chemgeo.2011.09.002 
Algeo, T.J., Heckel, P.H., Maynard, J.B., Blakey, R., Rowe, H., 2008. Modern and ancient epeiric seas and the super-estuarine circulation model of marine anoxia. Dynamics of Epeiric seas: sedimentological, paleontological and geochemical perspectives. Geological Association Canada Special Publication 7-38.

Armitage, J.H., 1962. Triassic Oil and Gas Occurrences in Northeastern British Columbia, Canada. Bulletin of Canadian Petroleum Geology 10, 35-56.

Arthur, M.A., Sageman, B.B., 1994. Marine Black Shales: Depositional Mechanisms and Environments of Ancient Deposits. Annual Review of Earth and Planetary Sciences 22, 499-551. doi:10.1146/annurev.ea.22.050194.002435

Arthur, M.A., Dean, W.E., 1998. Organic-matter production and preservation and evolution of anoxia in the Holocene Black Sea. Paleoceanography 13, 395-411. doi:10.1029/98PA01161

Bahlburg, H., Dobrzinski, N., 2011. Chapter 6 A review of the Chemical Index of Alteration (CIA) and its application to the study of Neoproterozoic glacial deposits and climate transitions. Geological Society, London, Memoirs 36, 81-92. doi:10.1144/M36.6

Baudin, F., Tribovillard, N., Trichet, J., 2007. Géologie de la matière organique. Société géologique de France: Vuibert.

Behar, F., Beaumont, V., De B. Penteado, H.L., 2001. Rock-Eval 6 Technology: Performances and Developments. Oil \& Gas Science and Technology 56, 111-134. doi:10.2516/ogst:2001013

Behar, F., Lorant, F., Lewan, M., 2008. Role of NSO compounds during primary cracking of a Type II kerogen and a Type III lignite. Organic Geochemistry 39, 1-22. doi:10.1016/j.orggeochem.2007.10.007

Bohacs, K.M., Carroll, A.R., Mankiewicz, P.J., Miskell-gerhardt, K.J., Schwalbach, J.O.N.R., Wegner, M.B., Simo, J.A.T., 2005. Production, destruction, and dilution-the many paths to sourcerock development, in: Harris, N.B. (Ed.), The Deposition Of Organic-Carbon-Rich Sediments : Models, Mechanisms and Consequences. Special Publications of SEPM, pp. 61-101.

Borisova, A.Y., Freydier, R., Polvé, M., Jochum, K.P., Candaudap, F., 2010. Multi-Elemental Analysis of ATHO-G Rhyolitic Glass (MPI-DING Reference Material) by Femtosecond and Nanosecond LA-ICP-MS: Evidence for Significant Heterogeneity of B, V, Zn, Mo, Sn, Sb, $\mathrm{Cs}, \mathrm{W}, \mathrm{Pt}$ and $\mathrm{Pb}$ at the Millimetre Scale. Geostandards and Geoanalytical Research 34, 245-255. doi:10.1111/j.1751-908X.2010.00077.x 
Brumsack, H.-J., 2006. The trace metal content of recent organic carbon-rich sediments: Implications for Cretaceous black shale formation. Palaeogeography, Palaeoclimatology, Palaeoecology 232, 344-361. doi:10.1016/j.palaeo.2005.05.011

Calvert, S.E., 1987. Oceanographic controls on the accumulation of organic matter in marine sediments. Geological Society, London, Special Publications 26, 137-151. doi:10.1144/GSL.SP.1987.026.01.08

Calvert, S.E., Bustin, R.M., Ingall, E.D., 1996. Influence of water column anoxia and sediment supply on the burial and preservation of organic carbon in marine shales. Geochimica et Cosmochimica Acta 60, 1577-1593. doi:10.1016/0016-7037(96)00041-5

Calvert, S.E., Pedersen, T.F., 1993. Geochemistry of Recent oxic and anoxic marine sediments: Implications for the geological record. Marine Geology 113, 67-88. doi:10.1016/00253227(93)90150-T

Calvert, S., Price, N.B., 1983. Geochemistry of Namibian Shelf Sediments, in: Suess, E., Thiede, J. (Eds.), Coastal Upwelling Its Sediment Record SE - 17, NATO Conference Series. Springer US, pp. 337-375. doi:10.1007/978-1-4615-6651-9_17

Canfield, D., 1993. Organic Matter Oxidation in Marine Sediments, in: Wollast, R., Mackenzie, F., Chou, L. (Eds.), Interactions of C, N, P and S Biogeochemical Cycles and Global Change SE - 14, NATO ASI Series. Springer Berlin Heidelberg, pp. 333-363. doi:10.1007/978-3-64276064-8_14

Catuneanu, O., Galloway, W.E., Kendall, C.G.S.C., Miall, A.D., Posamentier, H.W., Strasser, A., Tucker, M.E., 2011. Sequence Stratigraphy: Methodology and Nomenclature. Newsletters on Stratigraphy 44, 173-245. doi:10.1127/0078-0421/2011/0011

Chalmers, G.R.L., Bustin, R.M., 2012. Geological evaluation of Halfway-Doig-Montney hybrid gas shale-tight gas reservoir, northeastern British Columbia. Marine and Petroleum Geology 38, 53-72. doi:10.1016/j.marpetgeo.2012.08.004

Cowie, G.L., Hedges, J.I., 1992. The role of anoxia in organic matter preservation in coastal sediments: relative stabilities of the major biochemicals under oxic and anoxic depositional conditions. Organic Geochemistry 19, 229-234. doi:10.1016/0146-6380(92)90039-Z

Creaney, S., Passey, Q.R., 1993. Recurring Patterns of Total Organic Carbon and Source Rock Quality within a Sequence Stratigraphic Framework. AAPG Bulletin 77, 386-401.

Crombez, V., 2016. Petrofacies, sédimentologie et architecture stratigraphique des roches riches en matière organique. Etude multi-approches des formations Montney et Doig (Trias 
inférieur et moyen, Alberta and Colombie Britannique, Canada). PhD thesis, Université de Paris VI, 238p.

Crusius, J., Calvert, S., Pedersen, T., Sage, D., 1996. Rhenium and molybdenum enrichments in sediments as indicators of oxic, suboxic and sulfidic conditions of deposition. Earth and Planetary Science Letters 145, 65-78. doi:10.1016/S0012-821X(96)00204-X

Davies, G.R., 1997a. The Triassic of the Western Canada Sedimentary Basin: Tectonic and Stratigraphic Framework, Paleogeography, Paleoclimate and Biota. Bulletin of Canadian Petroleum Geology 45, 434-460.

Davies, G.R., 1997b. Aeolian Sedimentation and Bypass, Triassic of Western Canada. Bulletin of Canadian Petroleum Geology 45, 624-642.

Davies, G.R., Moslow, T.F., Sherwin, M.D., 1997. The Lower Triassic Montney Formation, WestCentral Alberta. Bulletin of Canadian Petroleum Geology 45, 474-505.

Demaison, G.J., Moore, G.T., 1980. Anoxic Environments and Oil Source Bed Genesis. AAPG Bulletin 64, 1179-1209.

Ducros, M., Euzen, T., Crombez, V., Sassi, W., Vially, R., n.d. 2-D basin modeling of the WCSB across the Montney-Doig system: implications for hydrocarbon migration pathways and unconventional resources potential, in M. AbuAli and I. Moretti, eds., Petroleum System Case Studies: AAPG Memoir 114. doi: 10.1306/13602027M1143703

Duyck, C., Miekeley, N., Porto da Silveira, C.L., Szatmari, P., 2002. Trace element determination in crude oil and its fractions by inductively coupled plasma mass spectrometry using ultrasonic nebulization of toluene solutions. Spectrochimica Acta Part B: Atomic Spectroscopy 57, 1979-1990. doi:10.1016/S0584-8547(02)00171-4

Einsele, G., 1992. Sedimentary basins: evolution, facies, and sedimentary budget. Springer-Verlag.

Emeis, K.-C., Whelan, J.K., Tarafa, M., 1991. Sedimentary and geochemical expressions of oxic and anoxic conditions on the Peru Shelf. Geological Society, London, Special Publications 58, 155-170. doi:10.1144/GSL.SP.1991.058.01.11

Emerson, S.R., Huested, S.S., 1991. Ocean anoxia and the concentrations of molybdenum and vanadium in seawater. Marine Chemistry 34, 177-196. doi:10.1016/03044203(91)90002-E 
Eppley, R.W., Peterson, B.J., 1979. Particulate organic matter flux and planktonic new production in the deep ocean. Nature 282, 677-680. doi:10.1038/282677a0

Espitalie, J., Deroo, G., Marquis, F., 1986. La pyrolyse Rock-Eval et ses applications. Première partie. Oil \& Gas Science and Technology 40, 563-579. doi:10.2516/ogst:1985035

Euzen, T., Everett, B., Power, M., Crombez, V., Rohais, S., Vaisblat, N., Baudin, F., 2015. Geological Controls on Reservoir Properties of the Montney Formation in Northeastern BC. An integration of sequence stratigraphy, organic geochemistry, quantitative mineralogy and petrophysical analysis, in: Geoconvention: Geoscience New Horizons. Calgary.

Golding, M.L., Mortensen, J.K., Ferri, F., Zonneveld, J.-P., Orchard, M., 2015a. Determining the provenance of Triassic sedimentary rocks in northeastern British Columbia and western Alberta using detrital zircon geochronology, with implications for regional tectonics. Canadian Journal of Earth Sciences. doi:10.1139/cjes-2015-0082

Golding, M.L., Orchard, M.J., Zonneveld, J.-P., Wilson, N.S.F., 2015b. Determining the age and depositional model of the Doig Phosphate Zone in northeastern British Columbia using conodont biostratigraphy. Bulletin of Canadian Petroleum Geology 63, 143-170.

Gottlieb, P., Wilkie, G., Sutherland, D., Ho-Tun, E., Suthers, S., Perera, K., Jenkins, B., Spencer, S., Butcher, A., Rayner, J., 2000. Using quantitative electron microscopy for process mineralogy applications. JOM 52, 24-25. doi:10.1007/s11837-000-0126-9

Grundman, G., Behar, F., Malo, M., Baudin, F., Lorant, F., 2012. Evaluation of hydrocarbon potential of the Paleozoic (Cambrian-Devonian) source rocks of the Gaspé Peninsula, Québec, Canada: Geochemical characterization, expulsion efficiency, and erosion scenario. AAPG bulletin 96, 729-751.

Hallam, A., 1985. A review of Mesozoic climates. Journal of the Geological Society 142, 433-445. doi:10.1144/gsjgs.142.3.0433

Haq, B.U., Hardenbol, J., Vail, P.R., 1988. Mesozoic and Cenozoic Chronostratigraphy and Cycles of Sea-Level Change, in: Wilgus, C.K., Hastings, B.S., Kendall, C.G.S.C., Posamentier, H.W., Ross, J.C., Van Wagoner, J.C. (Eds.), Sea-Level Changes: An Integrated Approach. Special Publications of SEPM.

Heckel, P.H., 1977. Origin of phosphatic black shale facies in Pennsylvanian cyclothems of midcontinent North America. AAPG Bulletin 61, 1045-1068.

Huc, A.Y., 1988. Aspects of depositional processes of organic matter in sedimentary basins. Organic Geochemistry 13, 263-272. doi:10.1016/0146-6380(88)90045-9 
Huc, A.Y., Van Buchem, F.S.P., Colletta, B., 2005. Stratigraphic Control on Source-Rock Distribution: First and Second Order Scale, in: Harris, N.B. (Ed.), . Special Publications of SEPM, pp. $225-242$.

Ibrahimbas, A., Riediger, C., 2004. Hydrocarbon source rock potential as determined by Rock-Eval 6/TOC pyrolysis, northeast British Columbia and Northwest Alberta, Resource Development and Geosciences Banch, Sumary of Activities 2004.

Ingall, E.D., Bustin, R.M., Van Cappellen, P., 1993. Influence of water column anoxia on the burial and preservation of carbon and phosphorus in marine shales. Geochimica et Cosmochimica Acta 57, 303-316. doi:10.1016/0016-7037(93)90433-W

Jarvie, D.M., 2012. Shale Resource Systems for Oil and Gas: Part 1-Shale-gas Resource Systems 6987. doi:10.1306/13321446M973489

Jarvie, D.M., Hill, R.J., Ruble, T.E., Pollastro, R.M., 2007. Unconventional shale-gas systems: The Mississippian Barnett Shale of north-central Texas as one model for thermogenic shalegas assessment. AAPG bulletin 91, 475-499.

Jones, B., Manning, D.A.C., 1994. Comparison of geochemical indices used for the interpretation of palaeoredox conditions in ancient mudstones. Chemical Geology 111, 111-129. doi:10.1016/0009-2541(94)90085-X

Karl, D.M., Knauer, G.A., Martin, J.H., 1988. Downward flux of particulate organic matter in the ocean: a particle decomposition paradox. Nature 332, 438-441. doi:10.1038/332438a0

Katz, B.J., 2005. Controlling Factors on Source Rock Development-A Review of Productivity, Preservation, and Sedimentation Rate, in: Harris, N.B. (Ed.), The Deposition Of OrganicCarbon-Rich Sediments : Models, Mechanisms and Consequences. Special Publications of SEPM, pp. 7-16.

Krajewski, K.P., 2013. Organic matter-apatite-pyrite relationships in the Botneheia Formation (Middle Triassic) of eastern Svalbard: Relevance to the formation of petroleum source rocks in the NW Barents Sea shelf. Marine and Petroleum Geology 45, 69-105. doi:10.1016/j.marpetgeo.2013.04.016

Lord, C.J., 1991. Determination of trace metals in crude oil by inductively coupled plasma mass spectrometry with microemulsion sample introduction. Analytical Chemistry 63, 15941599. doi:10.1021/ac00015a018 
McLennan, S.M., 2001. Relationships between the trace element composition of sedimentary rocks and upper continental crust. Geochemistry, Geophysics, Geosystems 2, n/a-n/a. doi:10.1029/2000GC000109

Monger, J., Price, R., 2002. The Canadian cordillera: Geology and Tectonic Evolution. CSEG Recorder $27,17-36$.

Myers, K.J., 1996. Organic-Rich Facies and Hydrocarbon Source Rocks, in: Sequence Stratigraphy. Blackwell Publishing Ltd., pp. 238-257. doi:10.1002/9781444313710.ch11

Nesbitt, H.W., Young, G.M., 1982. Early Proterozoic climates and plate motions inferred from major element chemistry of lutites. Nature $299,715-717$. doi:10.1038/299715a0

Orchard, M.J., Zonneveld, J.-P., 2009. The Lower Triassic Sulphur Mountain Formation in the Wapiti Lake area: lithostratigraphy, conodont biostratigraphy, and a new biozonation for the lower Olenekian (Smithian). Candian Journal of Earth Sciences 46, 757-790.

Parker, A., 2009. An Index of Weathering for Silicate Rocks. Geological Magazine 107, 501. doi:10.1017/S0016756800058581

Parrish, J.T., Curtis, R.L., 1982. Atmospheric circulation, upwelling, and organic-rich rocks in the Mesozoic and Cenozoic eras. Palaeogeography, Palaeoclimatology, Palaeoecology 40, 31-66. doi:10.1016/0031-0182(82)90084-0

Paulmier, A., Ruiz-Pino, D., 2009. Oxygen minimum zones (OMZs) in the modern ocean. Progress in Oceanography 80, 113-128. doi:10.1016/j.pocean.2008.08.001

Riediger, C.L., Brooks, P.W., Fowler, M.G., Snowdon, L.R., 1990. Lower and Middle Triassic source rocks, thermal maturation, and oil-source rock correlations in the Peace River Embayment area, Alberta and British Columbia. Bulletin of Canadian Petroleum Geology $38,218-235$.

Riediger, C.L., 1997. Geochemistry of Potential Hydrocarbon Source Rocks of Triassic Age in the Rocky Mountain Foothills of Northeastern British Columbia and West-Central Alberta. Bulletin of Canadian Petroleum Geology 45, 719-741.

Riquier, L., Tribovillard, N., Averbuch, O., Joachimski, M.M., Racki, G., Devleeschouwer, X., El albani, A., Riboulleau, A., 2005. Understanding Late Devonian And Permian-Triassic Biotic and Climatic Events - Towards an Integrated Approach, Developments in Palaeontology and Stratigraphy, Developments in Palaeontology and Stratigraphy. Elsevier. doi:10.1016/S0920-5446(05)80008-1 
Rohais, S., Crombez, V., Euzen, T., Baudin, F., 2016. The Montney-Doig-Halfway Formations from Western Canadian Sedimentary Basin (WCSB): Passive margin, Back-Arc or Fore-Arc geodynamic setting?, in: Geoconvention: Optimizing Resources. Calgary.

Rokosh, C.D., Lyster, S., Anderson, S.D.A., Beaton, A.P., Berhane, H., Brazzoni, T., Chen, D., Cheng, Y., Mack, T., Pana, C., Pawlowicz, J.G., 2012. Summary of Alberta's Shale- and SiltstoneHosted Hydrocarbon Resource Potential. Energy Resources Conservation Board.

Romero-Sarmiento, M.-F., Euzen, T., Rohais, S., Jiang, C., Littke, R., 2016. Artificial thermal maturation of source rocks at different thermal maturity levels: Application to the Triassic Montney and Doig Formation in the Western Canada Sedimentary Basin. Organic geochemistry 97, 148-162. doi:10.1016/j.orggeochem.2016.05.002

Sageman, B.B., Murphy, A.E., Werne, J.P., Ver Straeten, C.A., Hollander, D.J., Lyons, T.W., 2003. A tale of shales: the relative roles of production, decomposition, and dilution in the accumulation of organic-rich strata, Middle-Upper Devonian, Appalachian basin. Chemical Geology 195, 229-273. doi:10.1016/S0009-2541(02)00397-2

Sanei, H., Haeri-Ardakani, O., Wood, J.M., Curtis, M.E., 2015. Effects of nanoporosity and surface imperfections on solid bitumen reflectance (BRo) measurements in unconventional reservoirs. International Journal of Coal Geology 138, 95-102. doi:10.1016/j.coal.2014.12.011

Schoepfer, S.D., Shen, J., Wei, H., Tyson, R. V., Ingall, E., Algeo, T.J., 2014. Total organic carbon, organic phosphorus, and biogenic barium fluxes as proxies for paleomarine productivity. Earth-Science Reviews 149, 23-52. doi:10.1016/j.earscirev.2014.08.017

Schwarzkopf, T.A., 1993. Model for prediction of organic carbon content in possible source rocks. Marine and Petroleum Geology 10, 478-492. doi:10.1016/0264-8172(93)90049-X

Sellwood, B.W., Valdes, P.J., 2006. Mesozoic climates: General circulation models and the rock record. Sedimentary Geology 190, 269-287. doi:10.1016/j.sedgeo.2006.05.013

Slatt, R.M., Rodriguez, N.D., 2012. Comparative sequence stratigraphy and organic geochemistry of gas shales: Commonality or coincidence? Journal of Natural Gas Science and Engineering 8, 68-84. doi:10.1016/j.jngse.2012.01.008

Southam, J.R., Peterson, W.H., Brass, G.W., 1982. Dynamics of anoxia. Palaeogeography, Palaeoclimatology, Palaeoecology 40, 183-198. doi:10.1016/0031-0182(82)90089-X

Taylor, S.R., McLennan, S.M., 1985. The continental crust: Its composition and evolution. 
Tommeras, A., Mann, U., 2008. Improved hydrocarbon charge prediction by source-rock modelling. Petroleum Geoscience 14, 291-299. doi:10.1144/1354-079308-766

Tribovillard, N., Algeo, T.J., Lyons, T., Riboulleau, A., 2006. Trace metals as paleoredox and paleoproductivity proxies: An update. Chemical Geology 232, 12-32. doi:10.1016/j.chemgeo.2006.02.012

Tribovillard, N., Riboulleau, A., Lyons, T., Baudin, F., 2004. Enhanced trapping of molybdenum by sulfurized marine organic matter of marine origin in Mesozoic limestones and shales. Chemical Geology 213, 385-401. doi:10.1016/j.chemgeo.2004.08.011

Tyson, R. V, 1995. Sedimentary organic matter: organic facies and palynofacies. London, New York.

Tyson, R.V., 2001. Sedimentation rate, dilution, preservation and total organic carbon: some results of a modelling study. Organic Geochemistry 32, 333-339. doi:10.1016/S01466380(00)00161-3

Van Buchem, F.S.P., Pradier, B., Stefani, M., 2005. Stratigraphic Patterns in Carbonate Source-Rock Distribution: Second-Order to Fourth-Order Control and Sediment Flux, in: Harris, N.B. (Ed.), The Deposition Of Organic-Carbon-Rich Sediments : Models, Mechanisms and Consequences. Special Publications of SEPM, pp. 191-224.

Wakeham, S., Lee, C., 1993. Production, Transport, and Alteration of Particulate Organic Matter in the Marine Water Column, in: Engel, M., Macko, S. (Eds.), Organic Geochemistry SE - 6, Topics in Geobiology. Springer US, pp. 145-169. doi:10.1007/978-1-4615-2890-6_6

Wenzhöfer, F., Glud, R.N., 2004. Small-scale spatial and temporal variability in coastal benthic 02 dynamics: Effects of fauna activity. Limnology and Oceanography 49, 1471-1481. doi:10.4319/lo.2004.49.5.1471

Whitfield, M., 2001. Advances in Marine Biology V41, Advances in Marine Biology. Elsevier. doi:10.1016/S0065-2881(01)41002-9

Wignall, P.B., Newton, R., 2001. Black shales on the basin margin: a model based on examples from the Upper Jurassic of the Boulonnais, northern France. Sedimentary Geology 144, 335356. doi:10.1016/S0037-0738(01)00125-7

Wignall, P.B., 1991. Model for transgressive black shales? Geology 19, 167-170. doi:10.1130/00917613(1991)019 
Wilkin, R., Arthur, M., Dean, W., 1997. History of water-column anoxia in the Black Sea indicated by pyrite framboid size distributions. Earth and Planetary Science Letters 148, 517-525. doi:10.1016/S0012-821X(97)00053-8

Wood, J.M., Sanei, H., Curtis, M.E., Clarkson, C.R., 2015. Solid bitumen as a determinant of reservoir quality in an unconventional tight gas siltstone play. International Journal of Coal Geology. doi:10.1016/j.coal.2015.03.015

Zonneveld, J.-P., MacNaughton, R.B., Utting, J., Beatty, T.W., Pemberton, S.G., Henderson, C.M., 2010. Sedimentology and Ichnology of the Lower Triassic Montney Formation in the Pedigree-Ring/Border-Kahntah River Area, Northwestern Alberta and Northeastern British Columbia. Bulletin of Canadian Petroleum Geology 58, 115-140.

\section{FIGURES CAPTIONS}

Figure 1: Location map of the data available for this study. The names 0/06-33, 0/14-14 and 0/16-17, respectively stand for wells: 0/06-33-72-25W5, 0/14-14-76-12W6 and 0/16-17-83-25W6. The map on the upper right side indicates the location of the study area within the Western Canada sedimentary basin and the Montney Formation subcrop area. BC - British Columbia; AB - Alberta; CC - Canadian Cordillera; WCSB - Western Canada Sedimentary Basin; CS - Canadian Shield; UC - Ursula Creek outcrop; BH - Brown Hill outcrop.

Figure 2: Simplified sedimentary architecture of the Lower and Middle Triassic strata of the Western Canada sedimentary basin (modified from Crombez, 2016). On this sketch, the Brown Hill outcrop (BH) located near to Williston Lake in the fold and thrust belt of the Canadian Cordillera, was moved to its estimated original position at the time of deposition. TST - Transgressive systems tract; HST Highstand systems tract; FSST - Falling stage systems tract; LST - Lowstand systems tract.

Figure 3: A. HI vs Tmax cross-plots for core samples with TOC values. B. HI vs Tmax cross-plots for cuttings samples with TOC values. These figures show that most of the OM in the Montney and Doig Fm is Type II and Type III. Here, the increase of the TOC with the maturity is biased by the data sampling: in the basin the most mature areas contain the richest samples. $\mathrm{HI}-\mathrm{Hydrogen}$ index.

Figure 4: FID curves from the Basic Rock-Eval pyrolysis of an early mature cutting sample before and 
after hydrocarbons $(\mathrm{HC})$ extraction with organic solvent. HC extraction highlighted the presence of heavy HC in the S2 peak. FID - Flame lonization Detector; BR - Bulk Rock; eBR - Extracted Bulk Rock.

Figure 5: Palynofacies view of the Montney and Doig Fm. showing that most of the primary OM of the studied interval is amorphous. On these pictures only few terrestrial particles (spores, pollen grains or woody debris) are present and no damaged terrestrial particles can be observed. PM Palynomaceral $=$ Terrestrial organic matter; SP - Spore/Pollen; AOM - Amorphous organic matter; Py - Pyrite.

Figure 6: Well section across the Montney and Doig Fm with TOC measurements and estimations of the $\mathrm{TOC}_{\text {ini }}$ for two initial Hydrogen index $\left(\mathrm{IH}_{\mathrm{ini}}=350\right.$ and $\left.\mathrm{IH}_{\text {ini }}=600\right)$ in a stratigraphic framework. This figure shows that the organic content of sequence 3 and 4 is higher than in sequence 1 and 2 .

Figure 7: Distribution of the TOC and computed $\mathrm{TOC}_{\text {ini }}$ in the studied interval and in the four sequences. Solid bars represent actual TOC and hatched bars represent $\mathrm{TOC}_{\mathrm{in}}$. It shows that the mean TOC in the studied interval is $1.28 \mathrm{wt} \%$ and present heterogeneities: the TOC content of sequence 3 and TST4 is higher than the content of sequence 1 and 2.

Figure 8: Sedimentary section of sequences 3 and 4 from the core description of the 0/16-17-8325W6. This figure shows that low energy facies were dominant in the LST3 whereas during the TST4 high energy facies are dominant.

Figure 9: Cross-plots of the $\mathrm{TOC}_{\mathrm{ini}}$ and the SR. Here, SR are based on undecompacted sediments. White symbols show intervals where SR may be underestimated due to an erosional top. These cross-plots, present two types of relation between TOC $_{\text {ini }}$ and SR. In sequence 1, 2 and HST4 a linear relation exists between $\mathrm{TOC}_{\mathrm{ini}}$ and $\mathrm{SR}$ that reflect organic dilution by non-organic sediments. In sequence 3 and TST4, this relation is not evident which suggests others controls on organic accumulation and preservation.

Figure 10: Cross-plots of the enrichment factors (EF) of $\mathrm{Ni}$ and $\mathrm{Cu}$. The EF are computed based on the UCC (McLennan, 2001). Red lines in the cross-plots represent the Upper Continental Crust. This figure 
1022

1023

1024

1025

1026

1027

1028

1029

1030

1031

1032

1033

1034

1035

1036

1037

1038

1039

1040

1041

1042

1043

1044

1045

shows that paleoproductivity increased significantly in the TST4 whereas it remains stable in the rest of the studied interval.

Figure 11: Vertical evolution of paleoproductivity proxies ( $\mathrm{Cu} / \mathrm{Al}$ and $\mathrm{Ni} / \mathrm{Al})$ in relation to TOC and TOC $_{\text {ini. }}$ This figure shows that paleoproductivity increased significantly in the TST4 and that along Brown Hill, small increases of $\mathrm{Ni} / \mathrm{Al}$ often occur is sequence 2, but no increases in TOC can be related to these peaks.

Figure 12: Cross-plots of paleoredox proxies $(\mathrm{U} / \mathrm{Th}$ and $\mathrm{V} / \mathrm{Cr})$. Limit values between oxic/dysoxic/anoxic domains are from Jones and Manning (1994). This figure shows the occurrence of anoxic layers in sequence 3 and 4 .

Figure 13: Vertical evolution of paleoredox proxies (U/Th and Mo/Al) in relation to TOC and $\mathrm{TOC}_{\text {ini }}$ in the stratigraphic framework. This figure shows a major change above the SB3 and above the TS4/SB4. During sequence 3, the basin seems to be anoxic in its deepest parts whereas in the TST4, the basin presents anoxia to euxinia along its margin.

Figure 14: Cross-plot of the molybdenum versus the TOC in the stratigraphic framework. This figure shows that in the Lower and Middle Triassic strata of the western Canada sedimentary basin, the Mo/TOC ratio is low $\left(<30.10^{-4}\right)$ which suggests a basin restriction. SA: Saanich inlet; CB: Cariaco basin; FF: Framvaren fjord; BS: Black sea. Grey arrows highlight the potential effect of maturity on TOC values.

Figure 15: Cross-plot of the weathering index of Parker (WIP) and the chemical index of alteration $(\mathrm{CIA})$ in the stratigraphic framework. This cross-plot suggests that no major change of sediment maturity occurred during the Lower and Middle Triassic strata of the western Canada sedimentary basin.

Figure 16: TOC distribution and its controlling factors. This figure shows that high TOC values may result from different combinations of controlling factors 
1046 Figure 17: Conceptual models of basin types proposed for the controls of organic matter 1047 accumulations in the Lower and Middle Triassic of Western Canada. A. Type1: Oxic basin, with low 1048 OM accumulation. B. Type 2: Restricted basin, with the occurrence of organic rich layer in the central 1049 part of the basin due to stratified water. C. Type 3: High primary productivity basin, with the occurrence of organic rich intervals along the proximal parts of the basin due to high productivity. 


\section{ACCEPTED MANUSCRIPT}

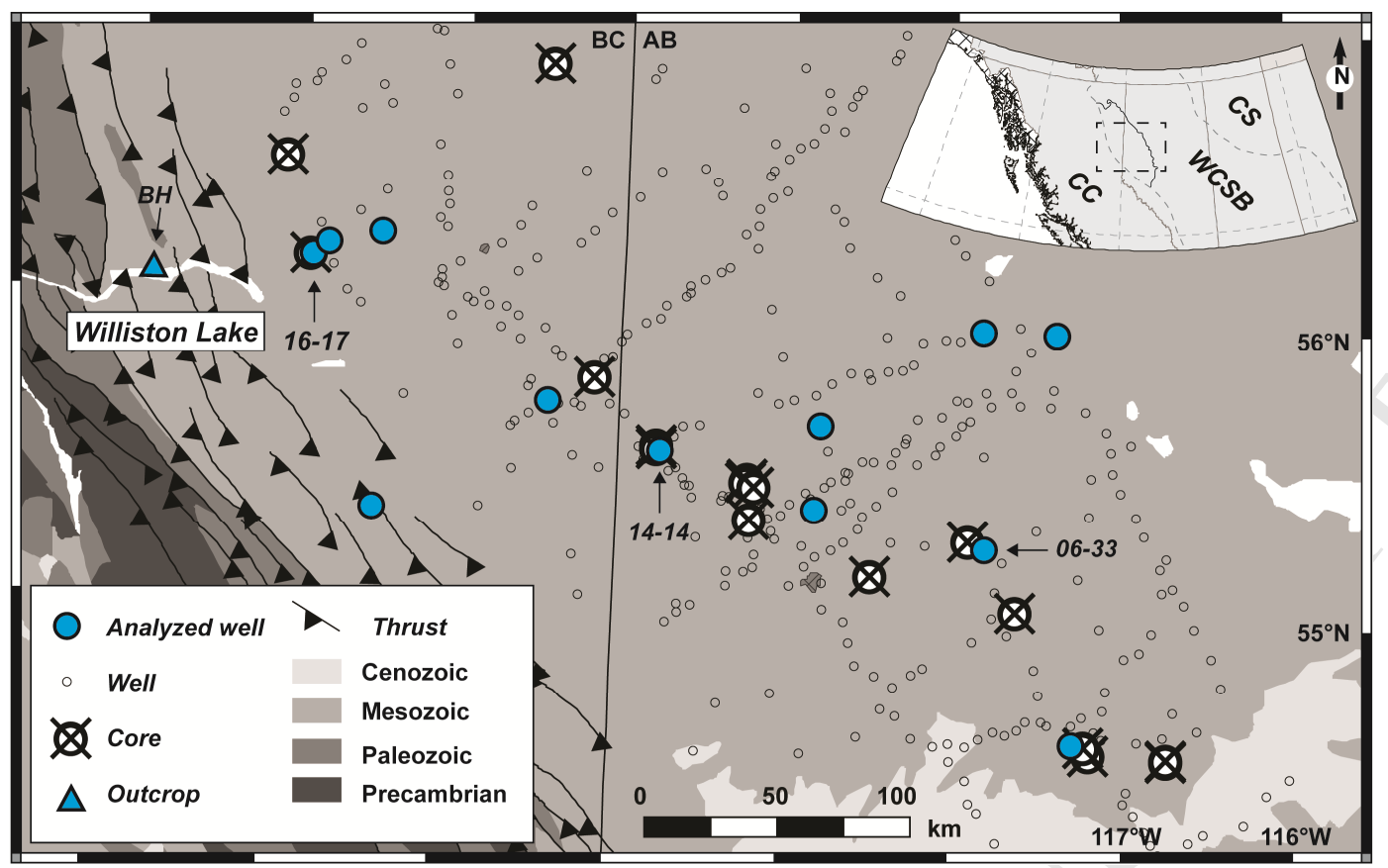




\section{ACCEPTED MANUSCRIPT}
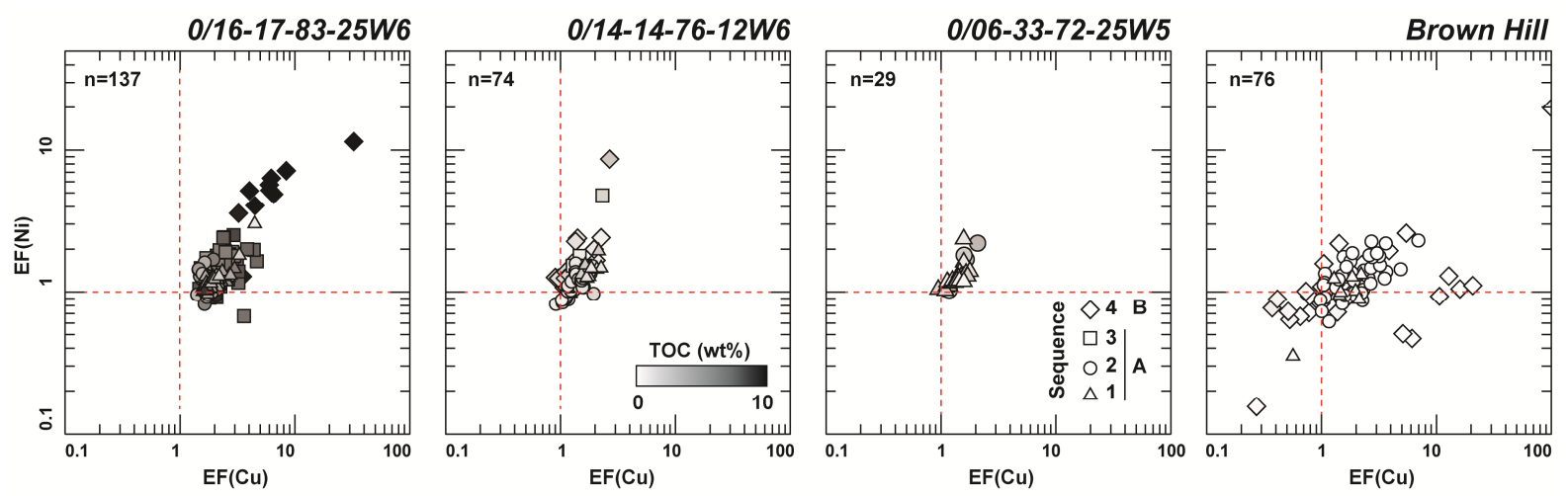


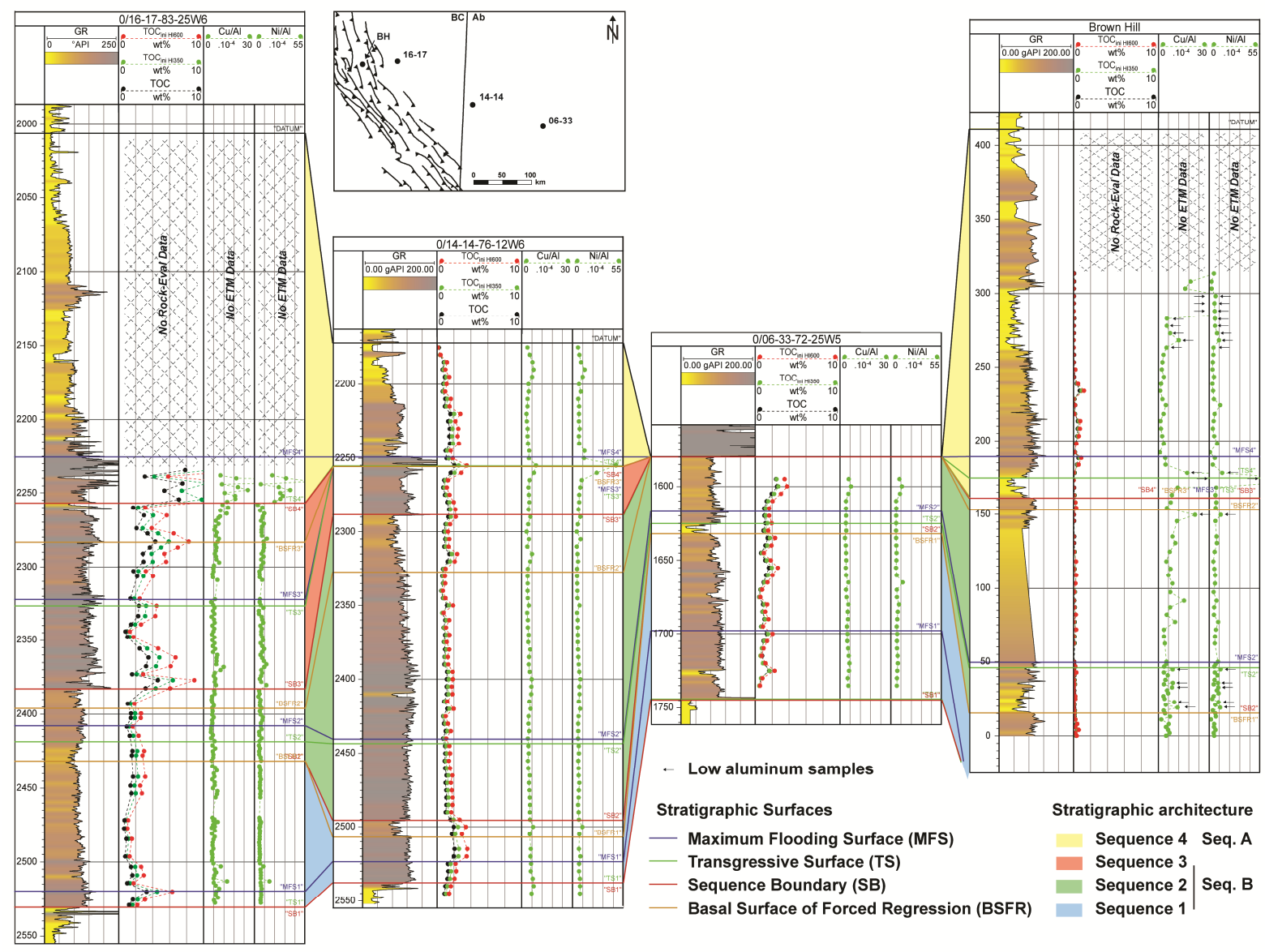




\section{ACCEPTED MANUSCRIPT}
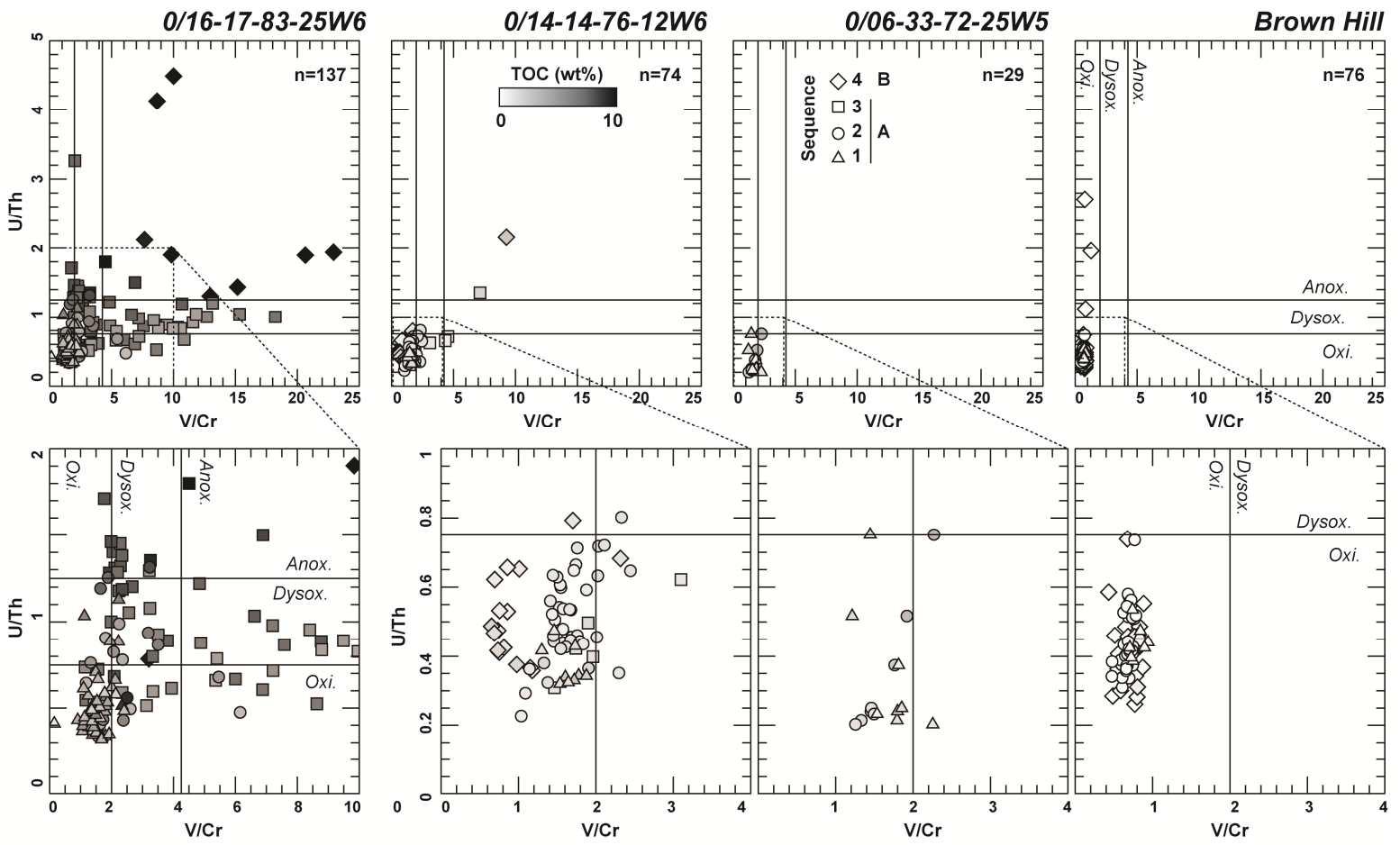

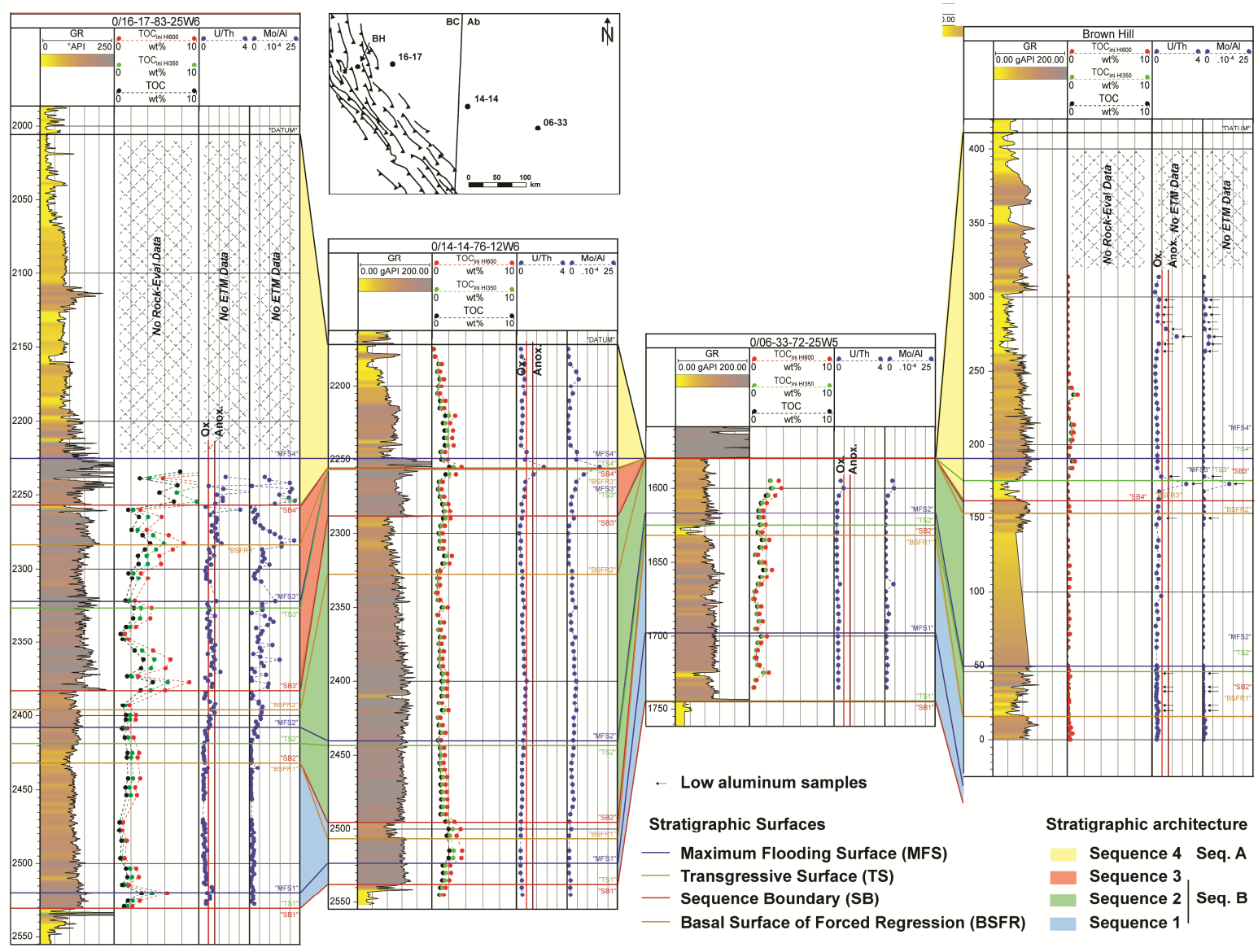

Stratigraphic Surfaces

Stratigraphic architecture

Maximum Flooding Surface (MFS)

Transgressive Surface (TS)

Sequence 4 Seq. A

\begin{tabular}{lr|r} 
Sequence Boundary (SB) & Sequence 2 & Seq. B \\
Basal Surface of Forced Regression (BSFR) & Sequence 1
\end{tabular}

Sequence 3 

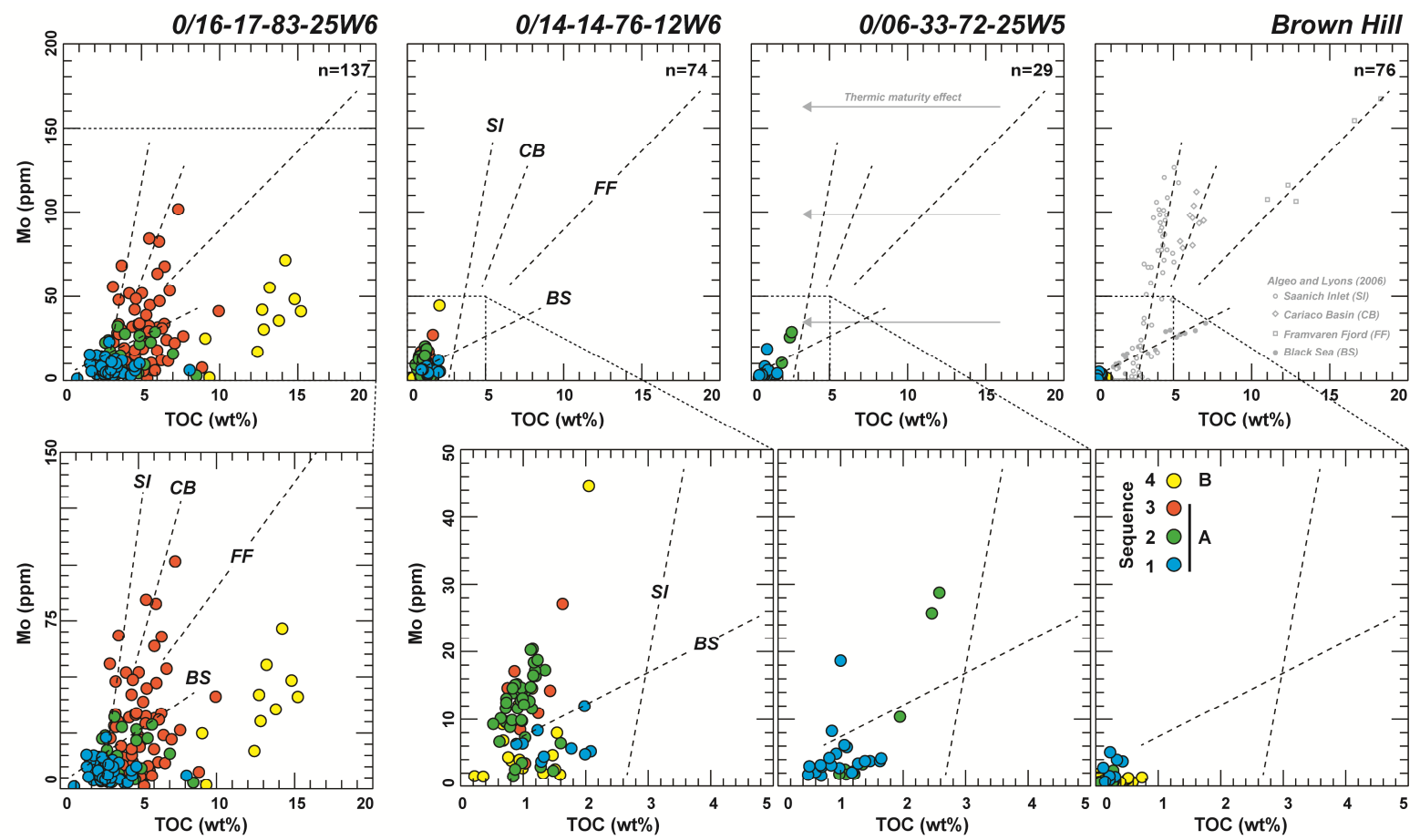


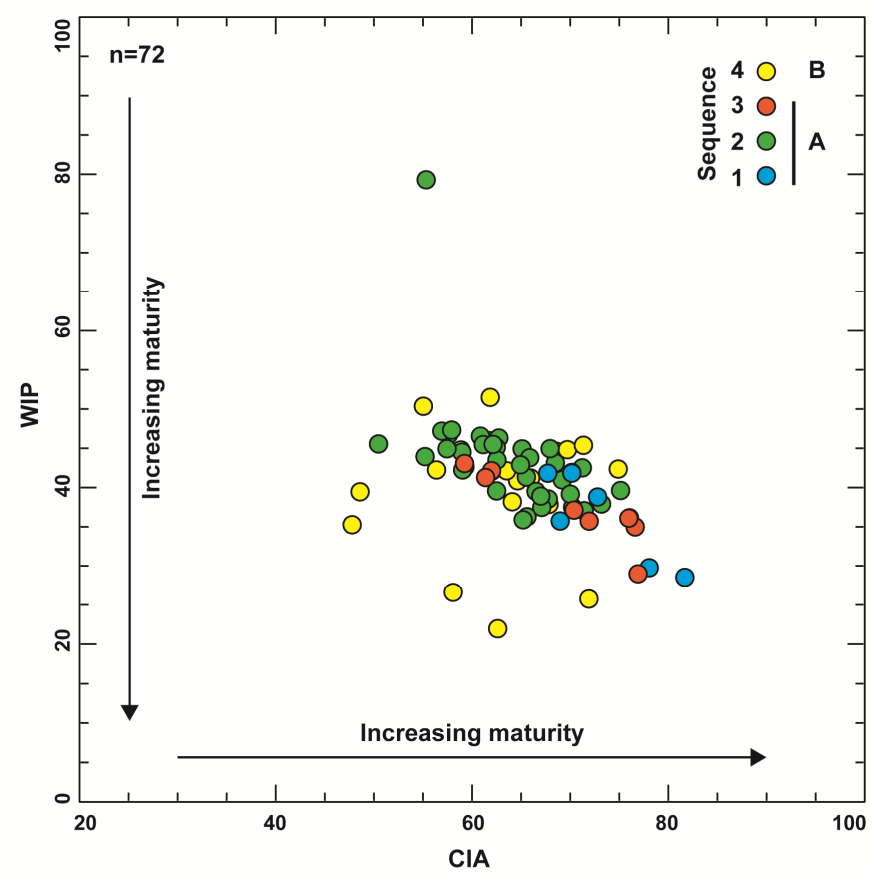




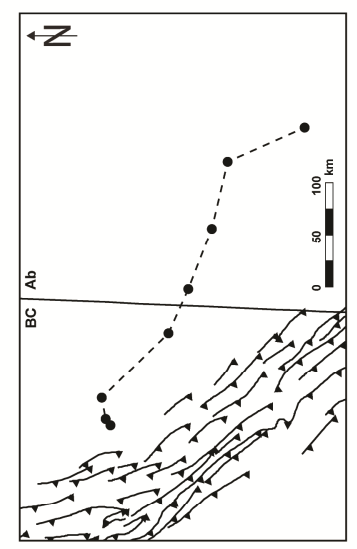

岕

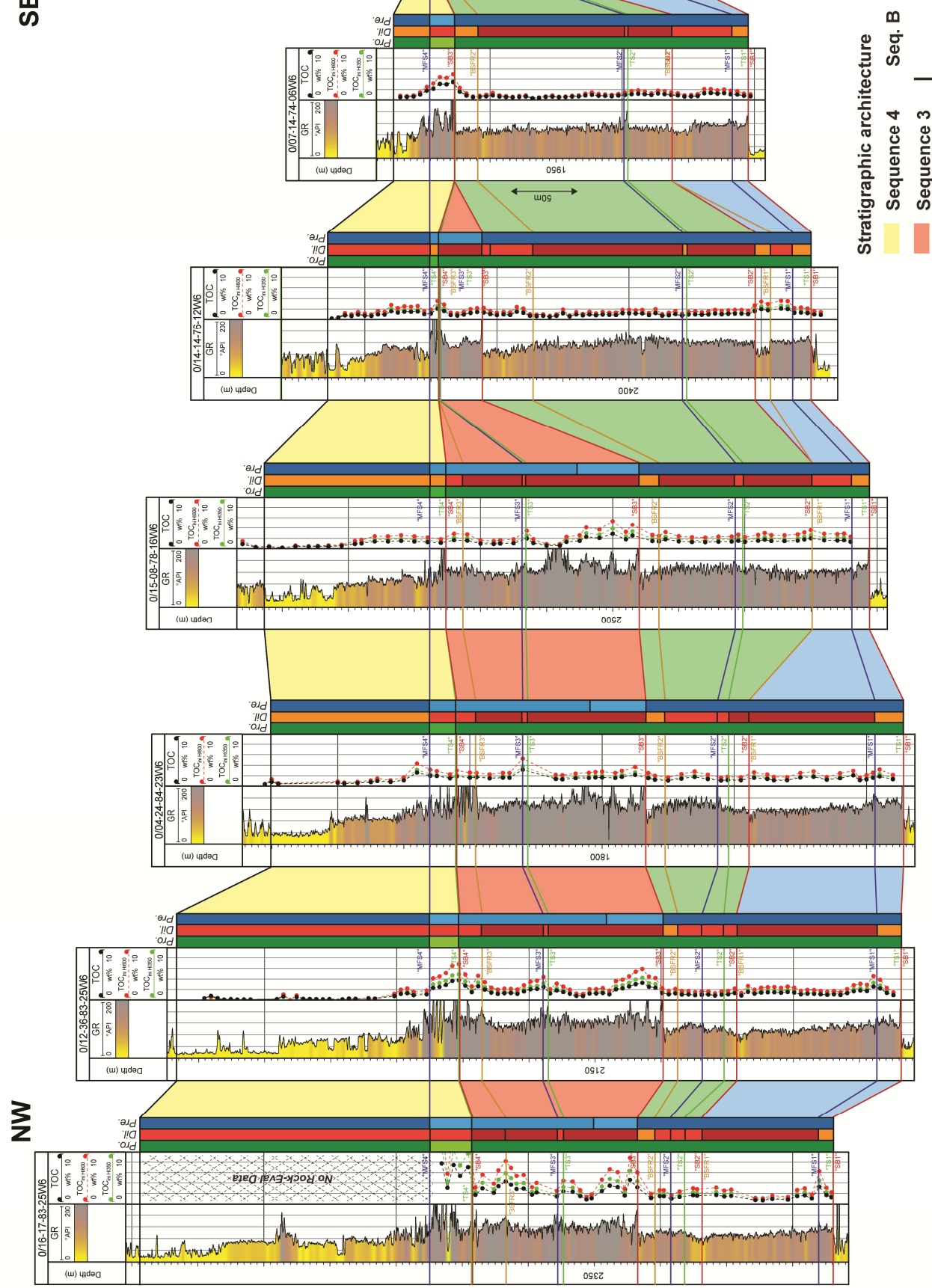

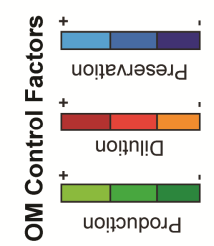

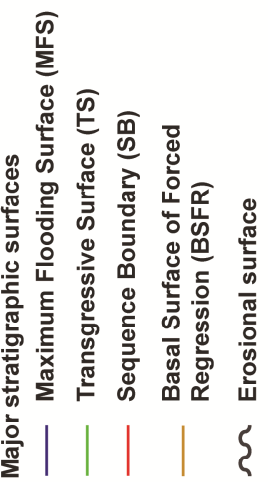

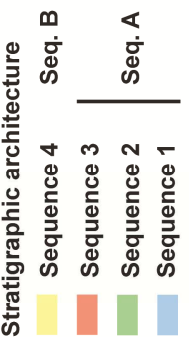




\section{C - Type 3: High primary productivity basin (TST4)}
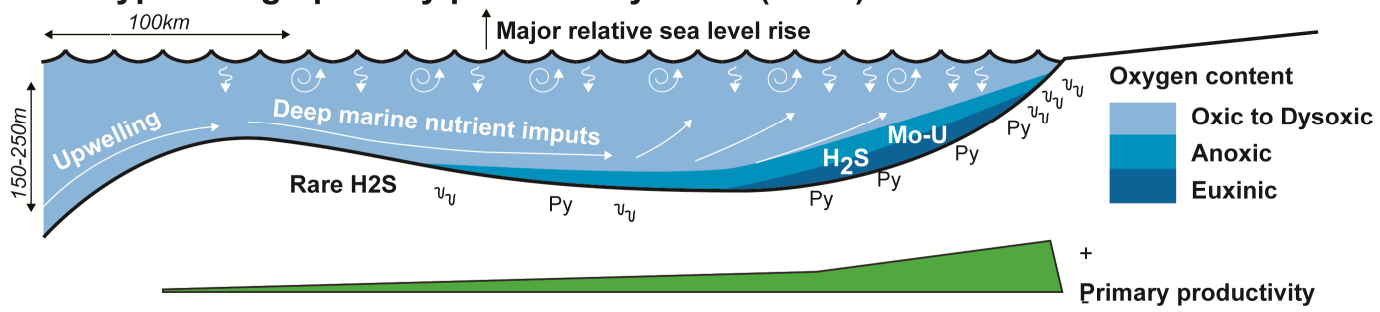

productivity

Sedimentation rates

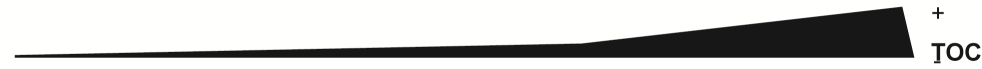

\section{B - Type 2: Restricted basin (Seq. 3)}
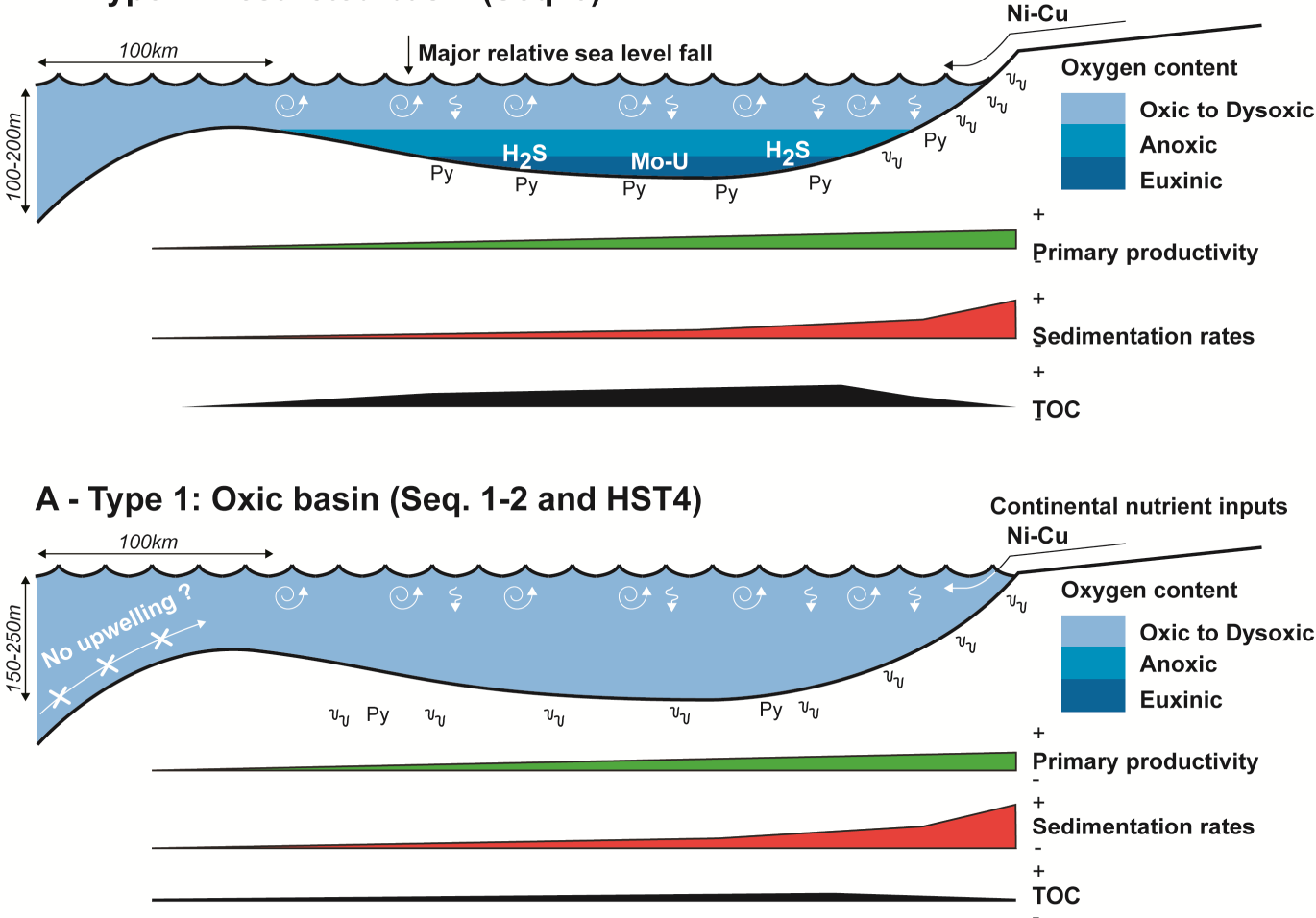

$v_{v}$ Bioturbations Py Pyrite $\quad$ Wave action $\$$ Sinking O.M 


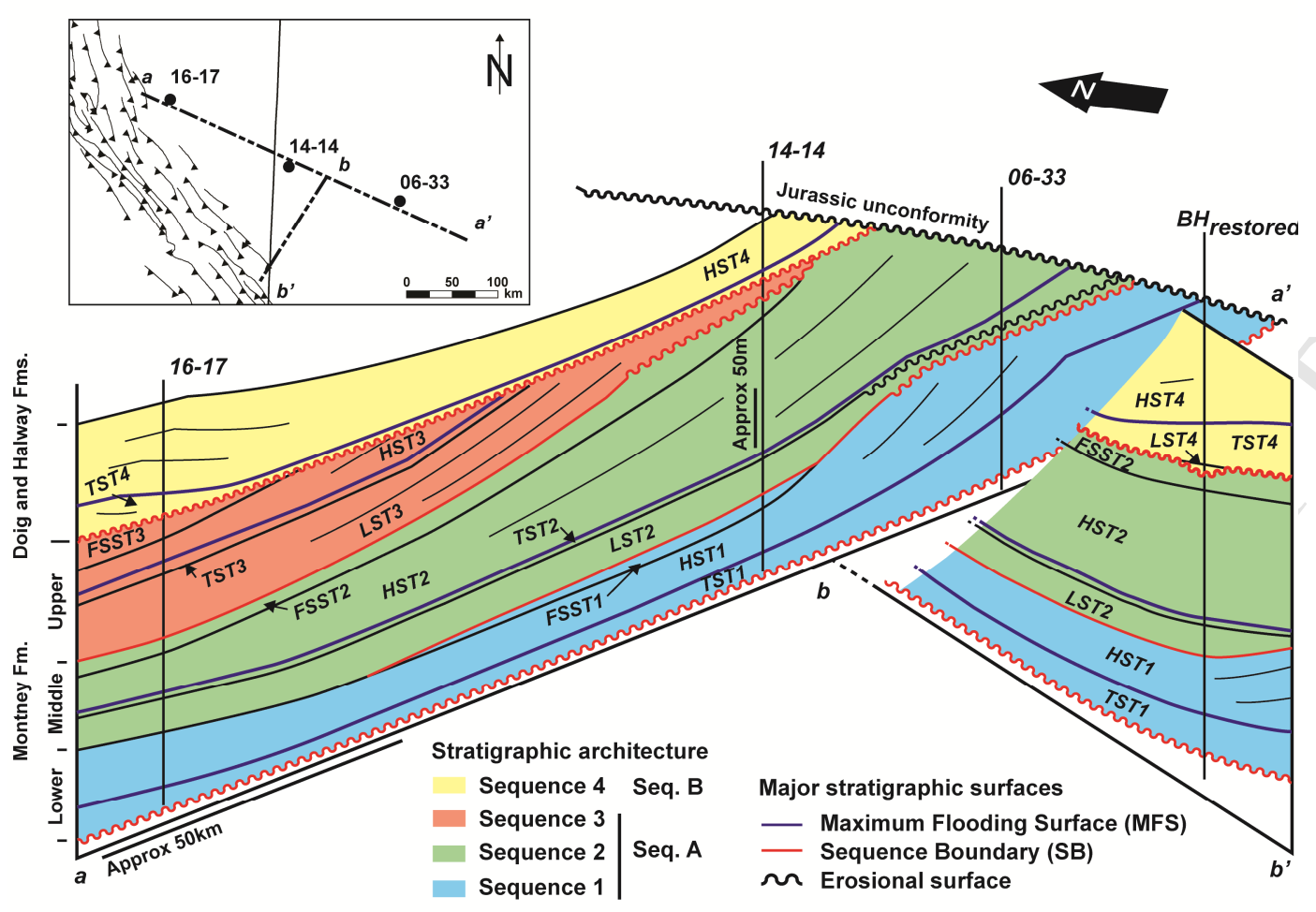



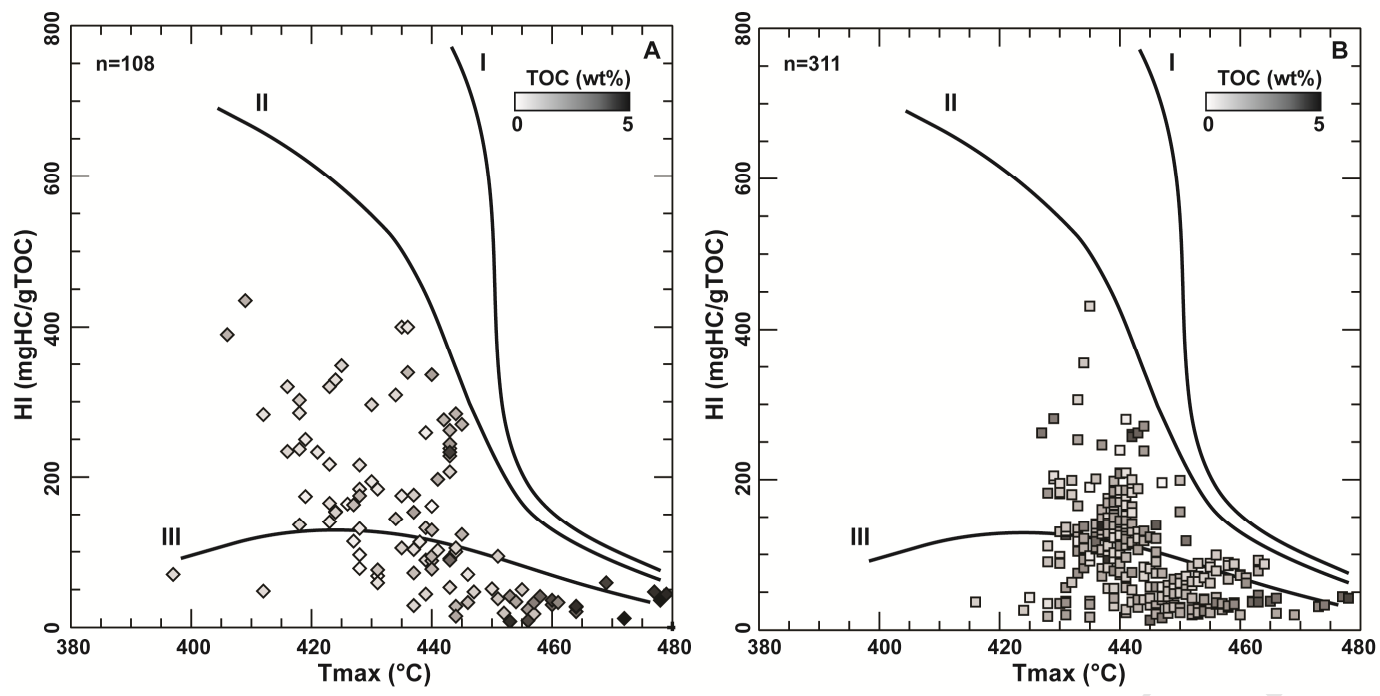


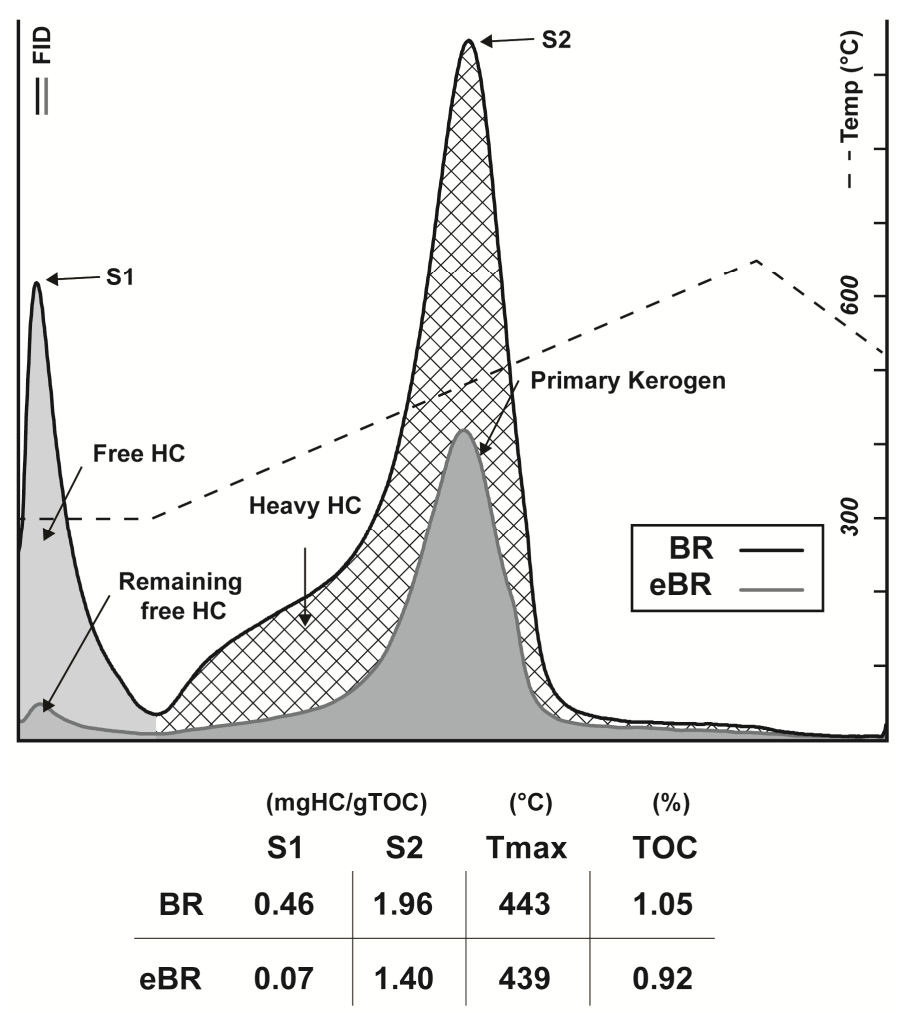



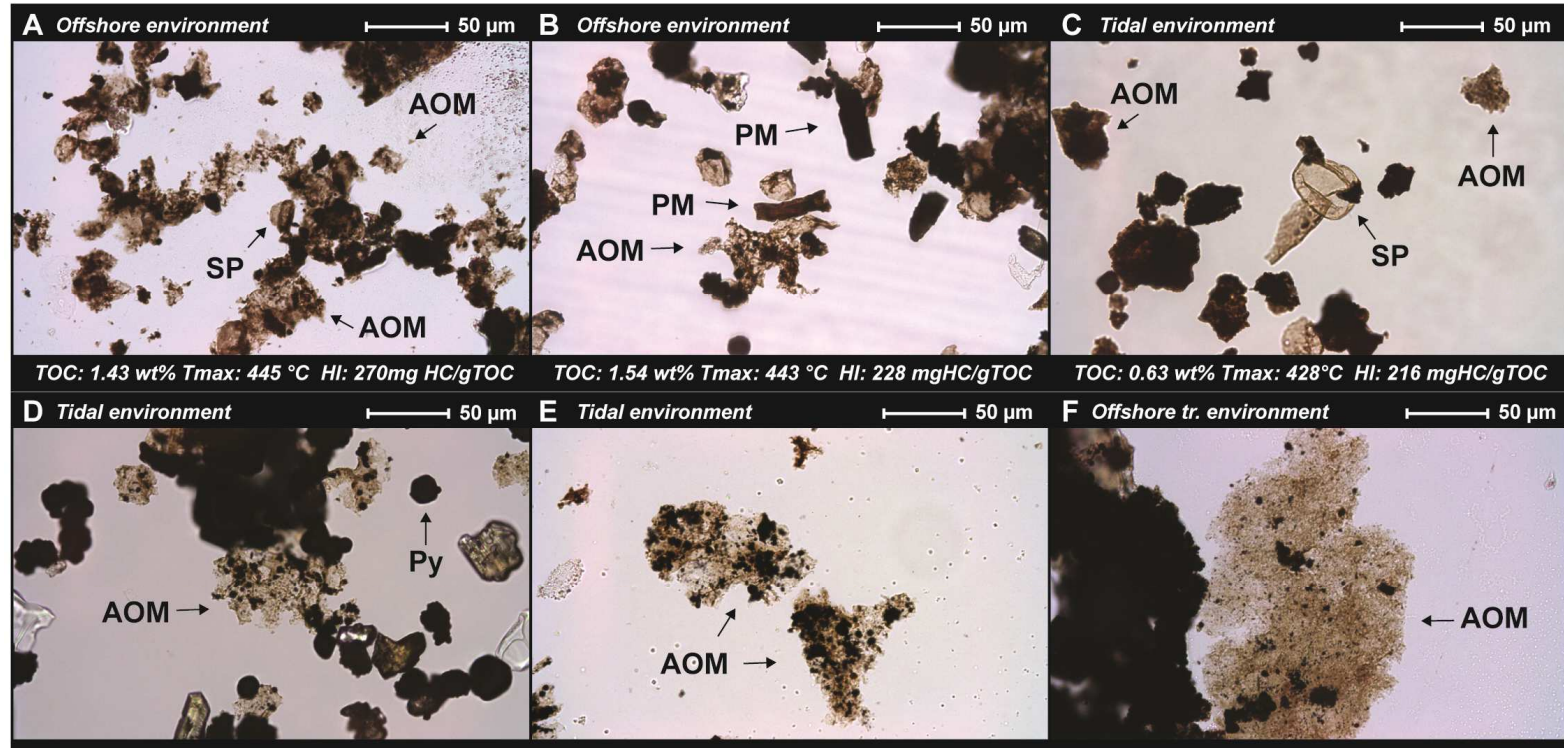

.63 w\% T Tmax: $428^{\circ} \mathrm{C}$ HI: 216 mgHC/gTOC

D Tidal environment

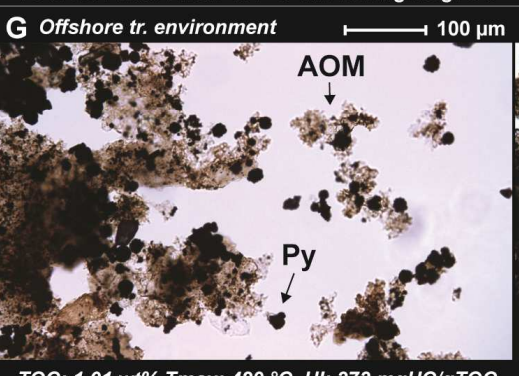

TOC: 0.74 wt\% Tmax: $434^{\circ} \mathrm{C}$ Hl: 309 mgHC/gTOC

F Offshore tr. environment

$\longmapsto 50 \mu \mathrm{m}$

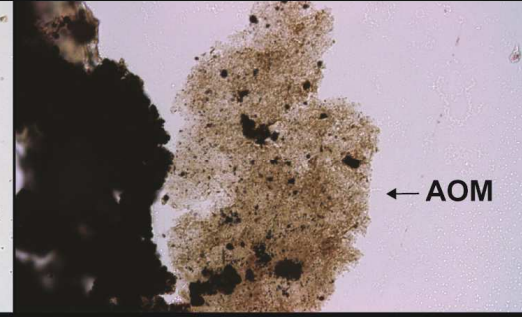

TOC: 2.81 wt\% Tmax: $436{ }^{\circ} \mathrm{C}$ Hl: $549 \mathrm{mgHC} / \mathrm{gTOC}$

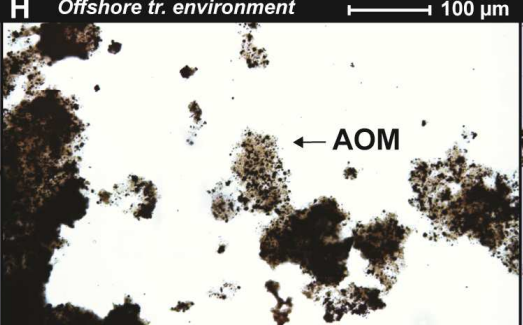

Offishore environment

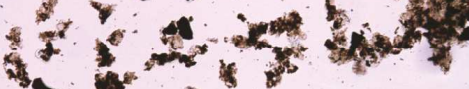

4. 7.5

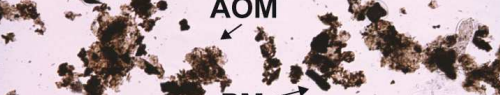

*

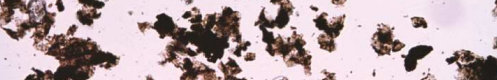

TOC: 1.01 wt\% Tmax: $429^{\circ} \mathrm{C} \mathrm{HI:} 373 \mathrm{mgHC} / \mathrm{gTOC}$ 

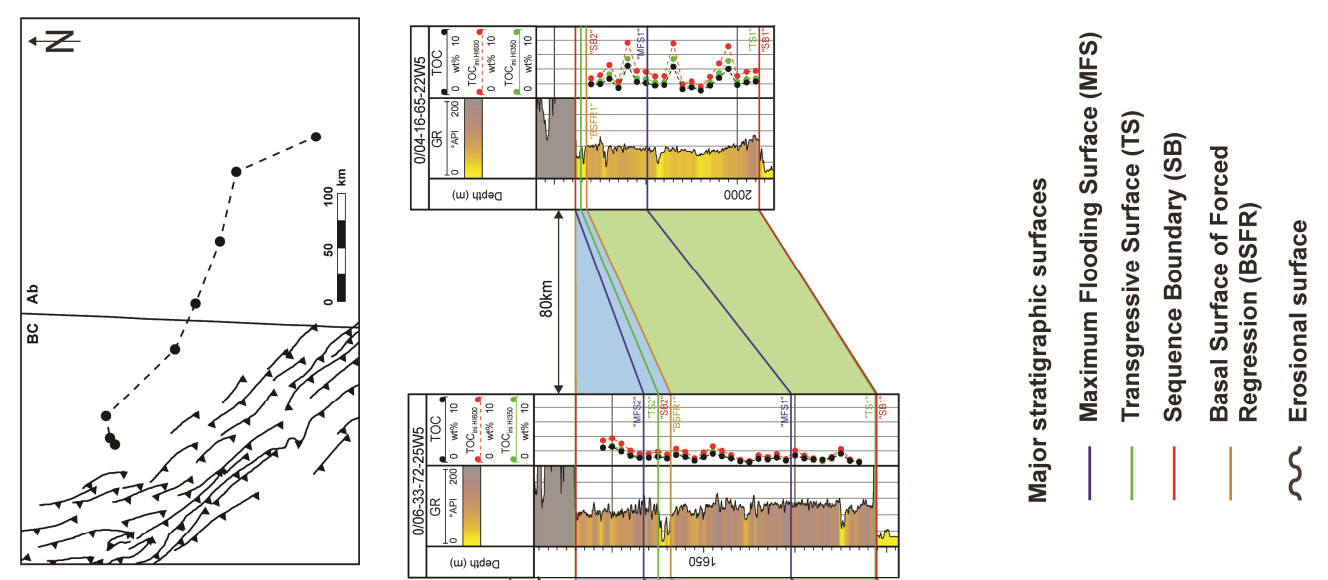

๗

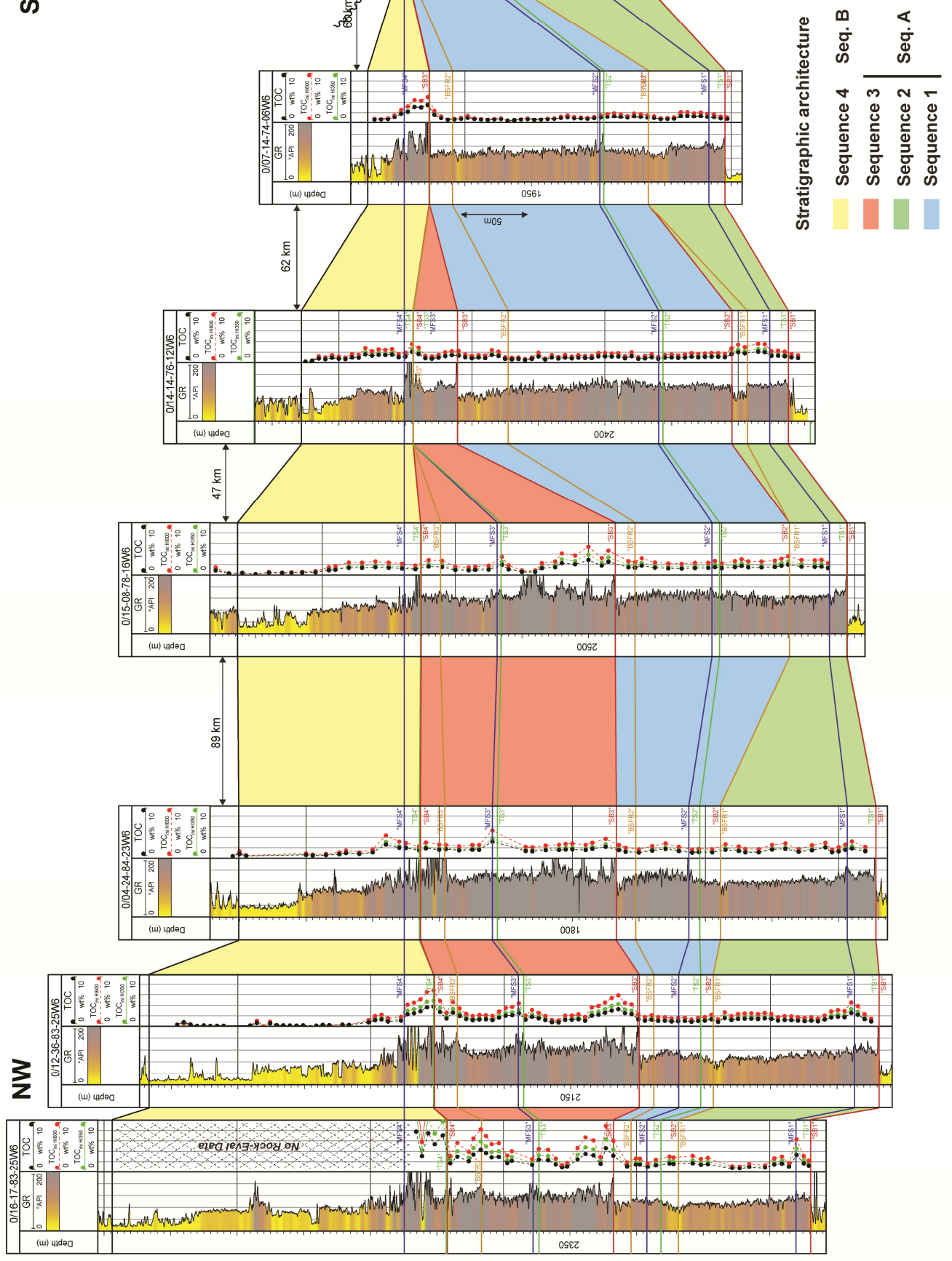



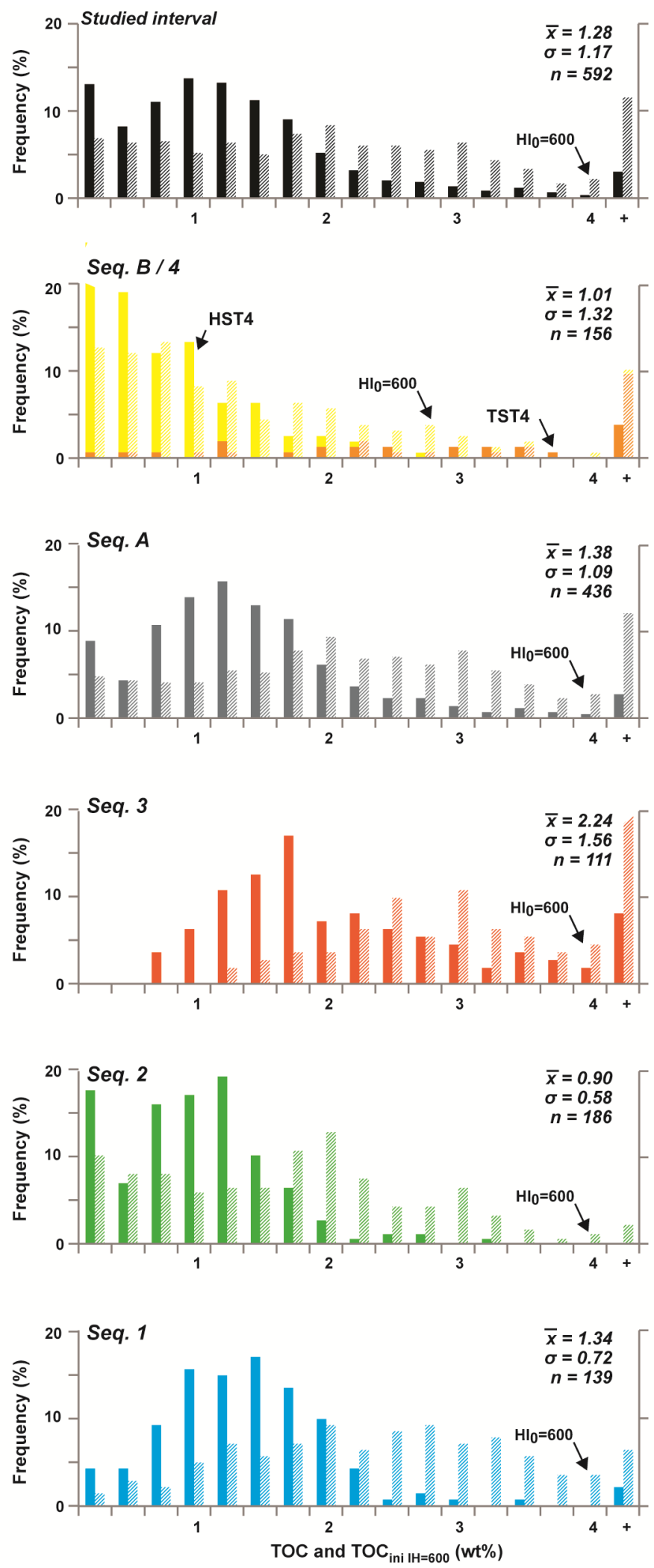


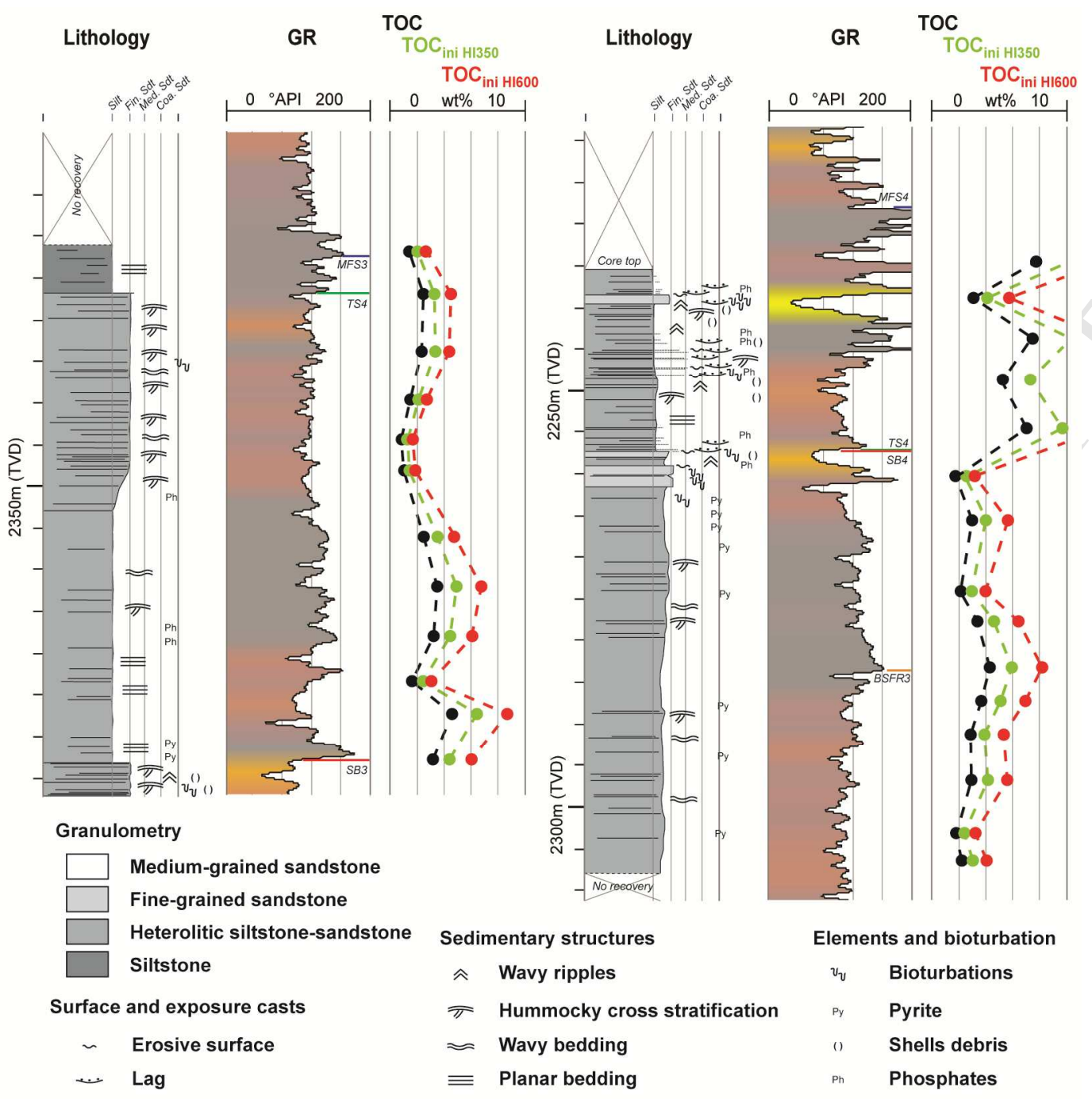




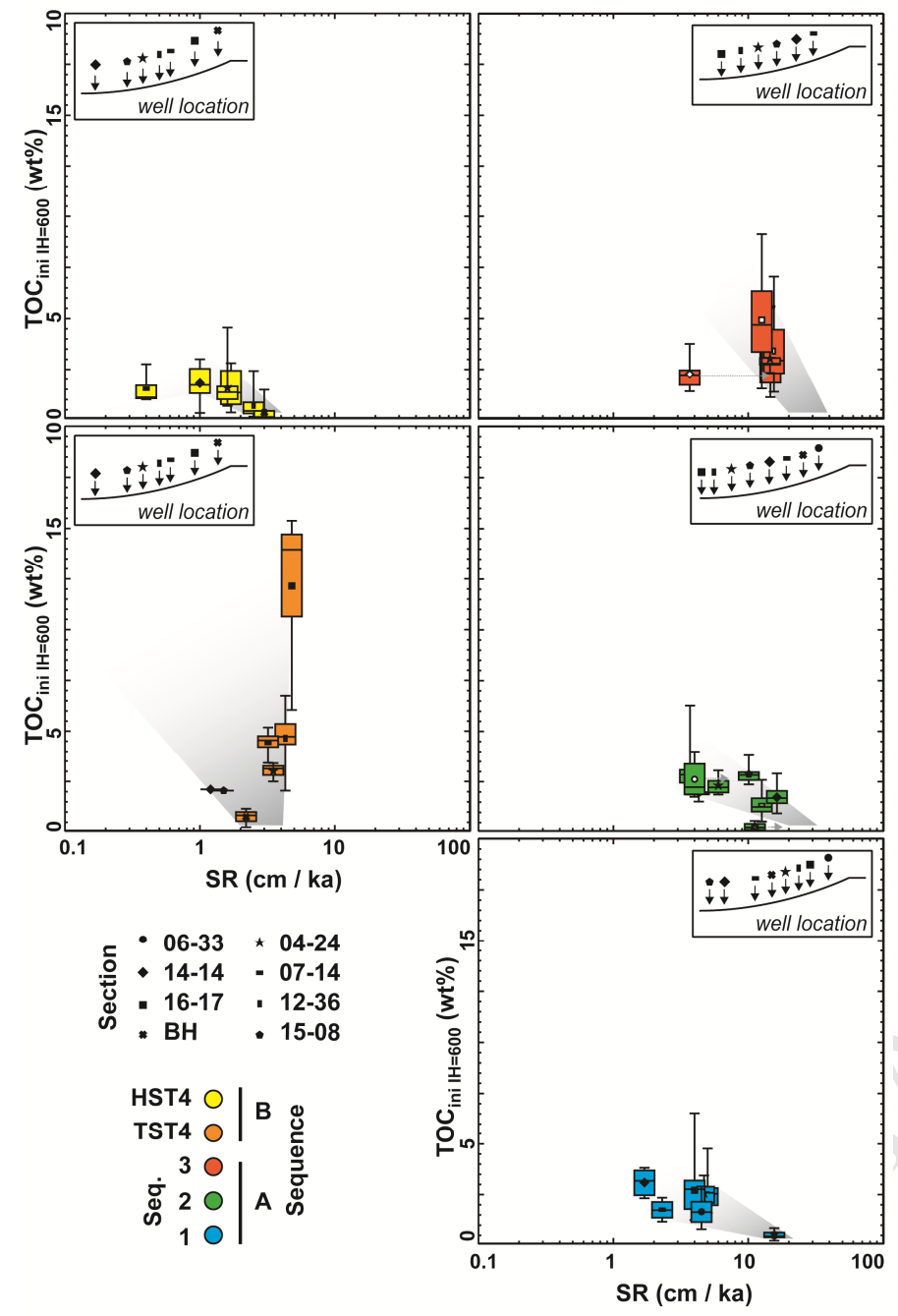

